\title{
تأثير الرضا الوظيفي في الأداء المنظمي \\ دراسة تحليلية في الشركة العامة لصناعة البطاريات
}

م. بشرى عباس محمد

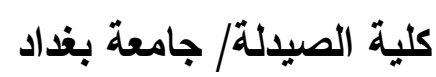

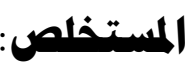

يهتم البحث بلراسة العلاقة والأثر بين متغيرين رئيسين هما: الرضا الوظيفي وضم ستة متغيرات فرعية

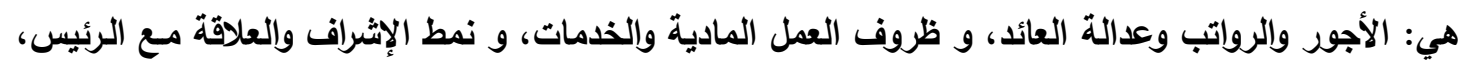

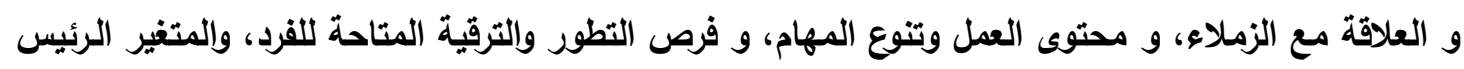

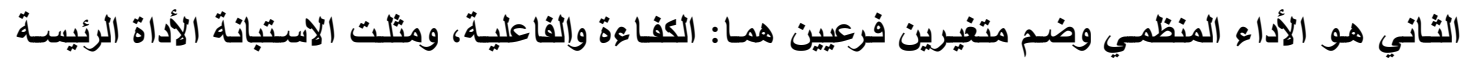

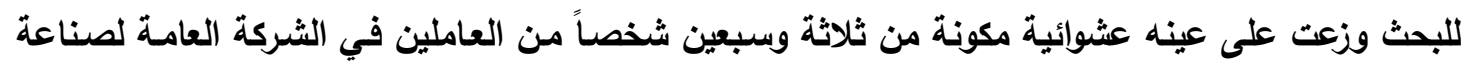

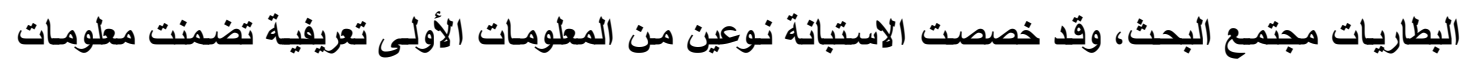
عامة عن عينة الدراسة، والثاني ذات علاقة بمتغيرات الدراسة ضمت ستة وأريعون سؤالا.

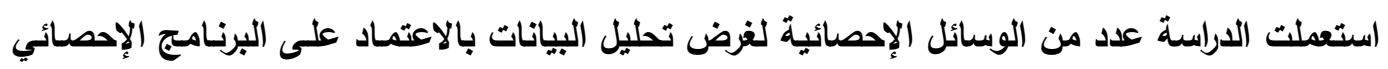

الجاهز SPS.20. (الجز

من ابرز النتائج التي توصل اليها البحث وجود علاقة موجبة بين الرضا الوظيفي والأداء المنظمي ويؤثر

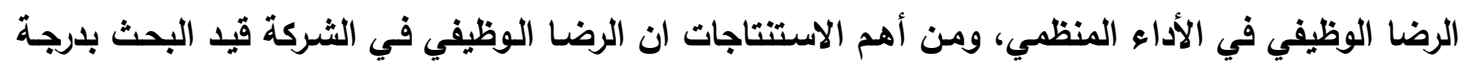

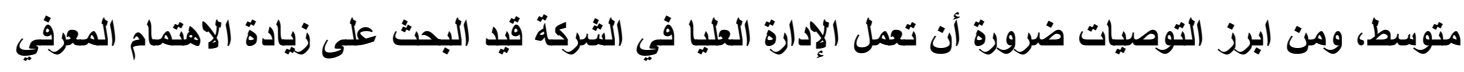

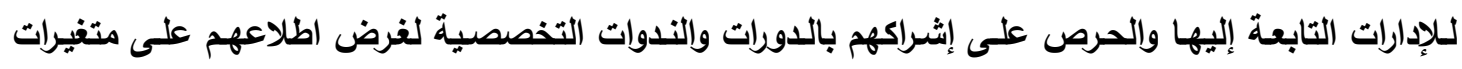
الرضا الوظيفي ومدى تأثيره على أداء الشركة وأن ذلك يتطلب قيادات تؤمن بأهمية بالرضا الورات الوظيفي.

الإسطات الرئيسية للبحث/ الرضا الوظيفي- الأداء المنظي- الكفاءة، الفاعلية.

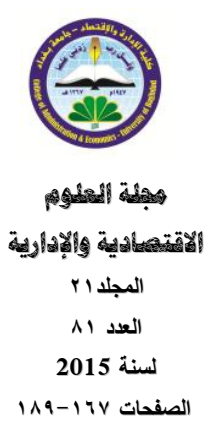




\section{العامة لصناعة البطاريات}

هقدهة:

اهتم الباحثون في مجال السلوك التنظيمي وعلم النفس الصناعي وعلم الاجتماع بدراسة العوامل المؤثرة في الأداء المنظمي، وقد نال الرضا الوظيفي حظا وافرا من اهتمام المدرسـة السلوكية الحديثة لما تتركه متغيراتهـ

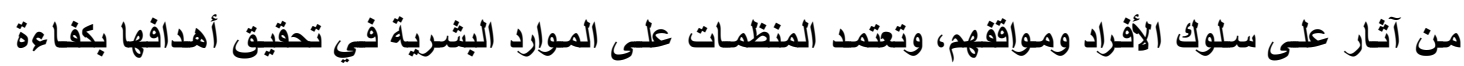

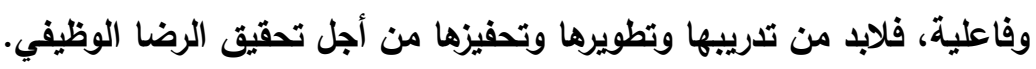

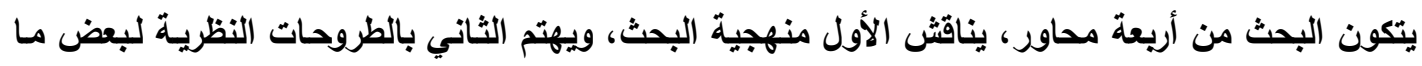

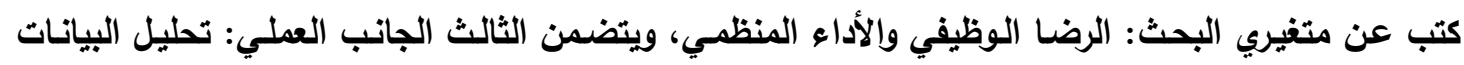

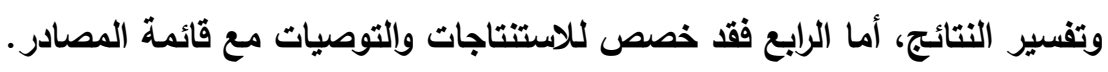

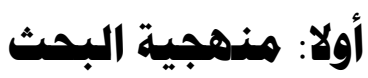

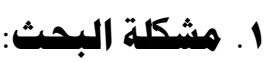

يعد مفهوم الرضا الوظيفي من المفاهيم السلوكية بالغة التعقيد لارتباطه بمشاعر الفرد والتي غالبا ما

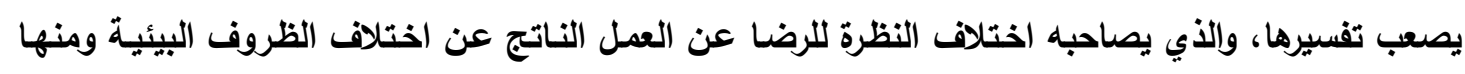

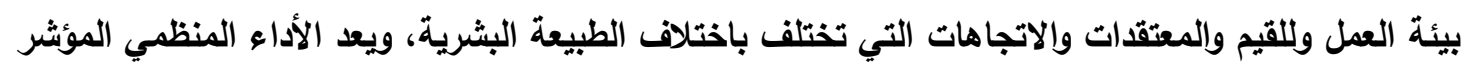

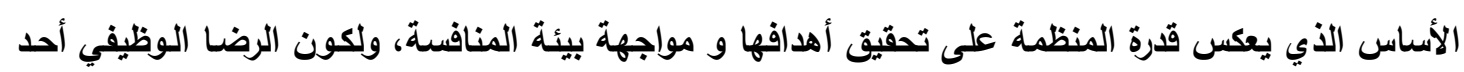

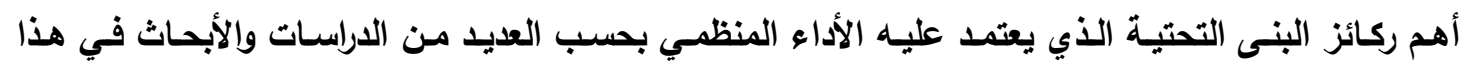
المجال، يتصدى البحث لمشكلة حقيقية تكمن في مدى اهتمام الإدارات في منظماتنا الصناعية ومنها الشركة لهئة

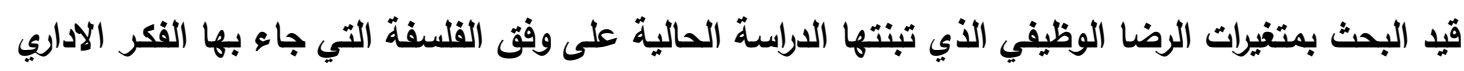
المعاصر وتأثير هذه المتغيرات في أداء الثركة، ويمكن التعبير عن مشكلة البحث بالتساؤلات الآتية:

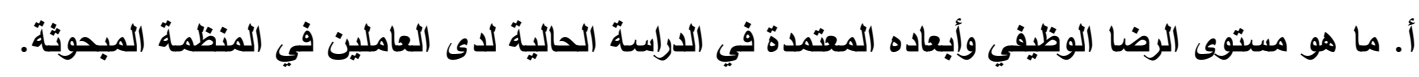
ب. ما هو مستوى تأثير متغيرات الرضا الوظيفي المعتمدة في الاراسة الحالية في أداء المنظمة المبحوثة.

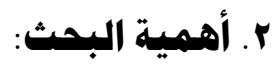

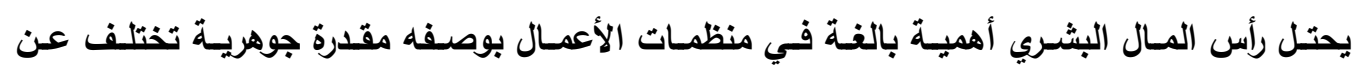
موجودات المنظمة الملموسة الأخرى، مما جعل المنظمات في تسابق للحصول على رضا العاملين فيها والذي فئي

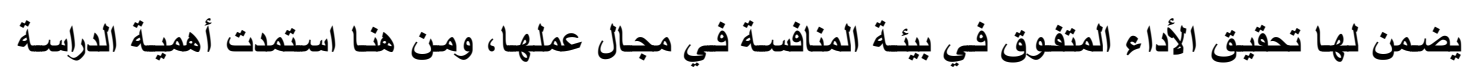

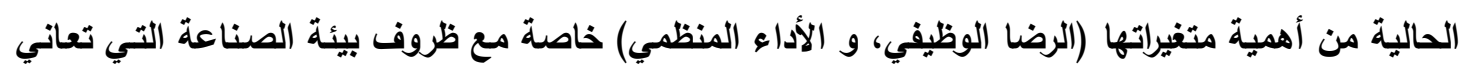

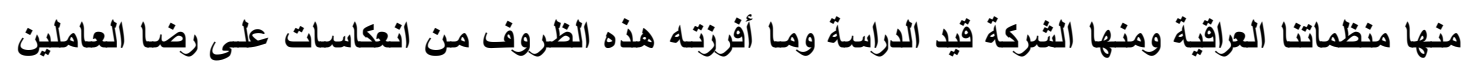
فيها وإنعكاساته بدوره على أداء الثركة قيد الدراسة.

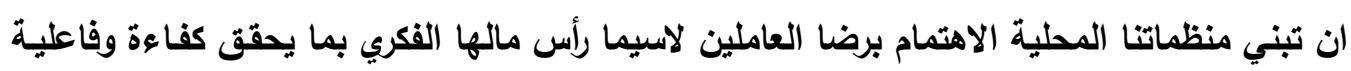
الأداء فيها، لابد أن يؤدي دورا مهما في تعزيز الثقة بمنتجاتها لدى المستهلكين ويضمن استمرارها ويقائها في بيئة شديدة المنافسة. 


\section{العامة لصناعة البطاريات}

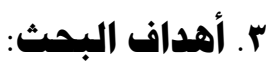

يحاول البحث تحقيق ما يأتي:

أ. المساهمة في الإثراء المعرفي من خلال رفد المكتبة العراقية بمضامين متغيرات البحث. ب. التعرف على مدى تطبيق متغيرات الرضا الوظيفي على أرض الواقع في الشركة قيد البحث.

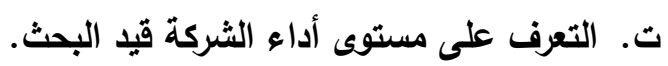
ث. تحليل العلاقة بين متغيرات الرضا الوظيفي ومتغيرات الأداء المنظمي في الثركة قيد البحث. ج. قياس أثر متغيرات الرضا الوظيفي في متغيرات الأداء في الثركة قيد البحث.

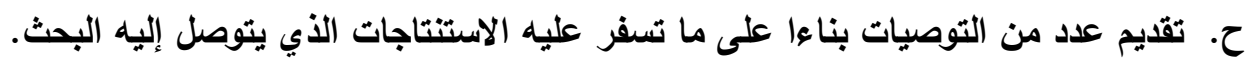

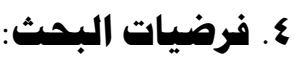

يحاول البحث اثبات صحة الفرضيات الآتية:

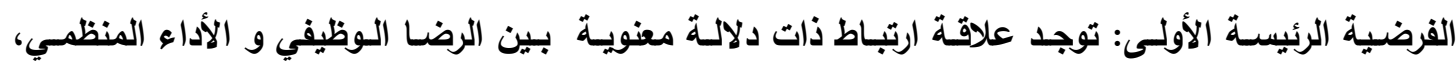
ويتفرع عنها الفرضيات الآتية: أ- توجد علاقة ارتباط ذات دلالة معنوية بين محتوى العمل و الأداء المنظمي.

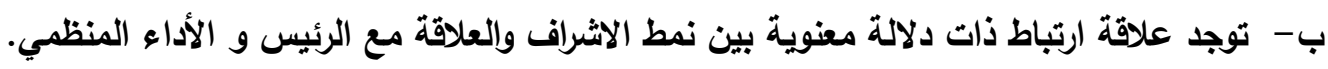
ت- توجد علاقة ارتباط ذات دلالة معنوية بين العلاقة مع الزملاء و الأداء المنظمي.

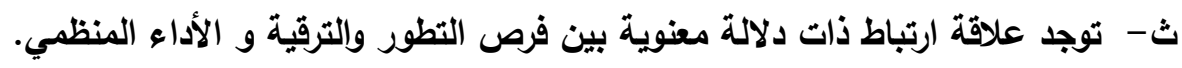

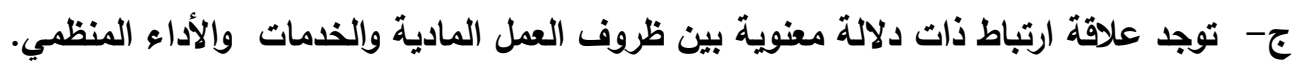
ح- توجد علاقة ارتباط ذات دلالة معنوية بين الأجور والرواتب وعدالة العائد و الأداء المنظمي.

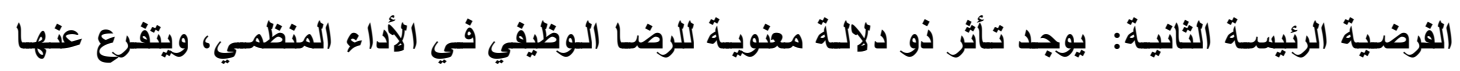
الفرضيات الآتية: أ. يوجد تأثير ذو دلالة معنوية لمحتوى العمل في الأداء المنظمي.

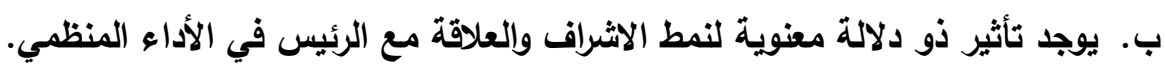

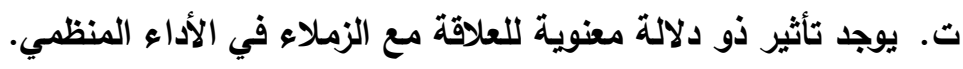
ث. يوجد تأثير ذو دلالة معنوية لفرص التطور والترقية في الأداء المنظمي.

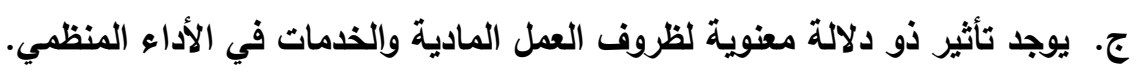

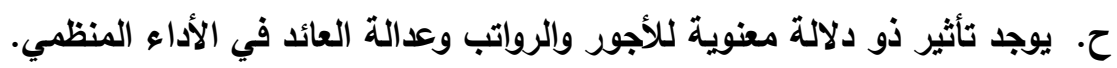
ه. المخطط الفرضي للبحث: يوضح الثكل (1) المخطط الفرضي للبحث: 


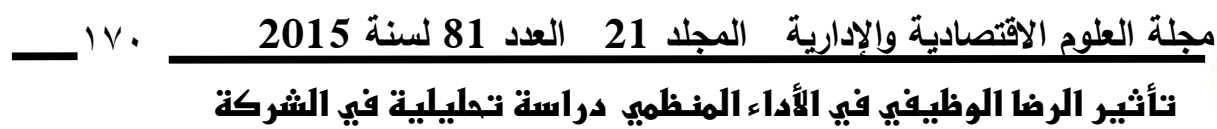

\section{العامة لصناعة البطاريات}

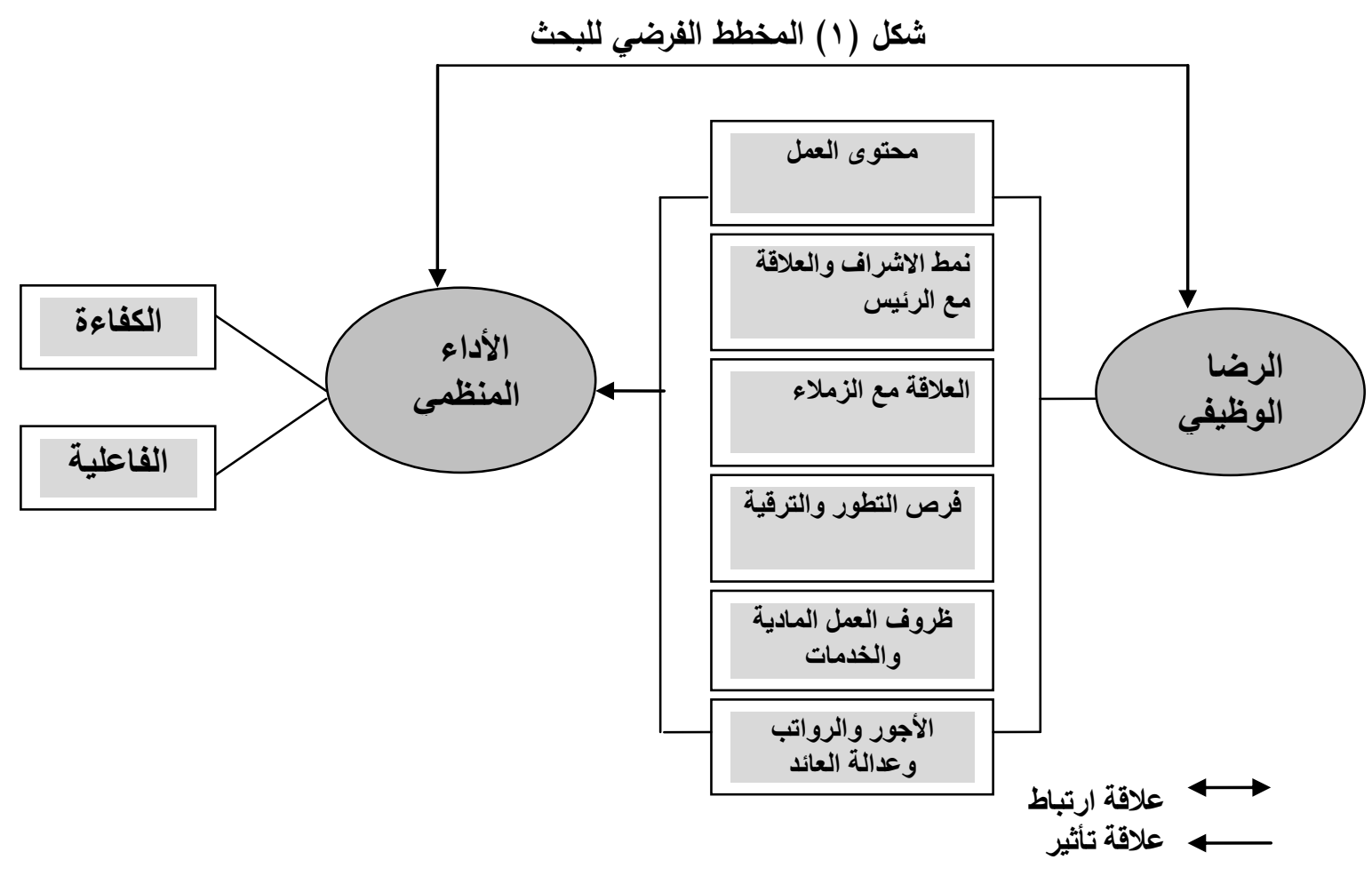

1. اسلوب جمع البيانات:

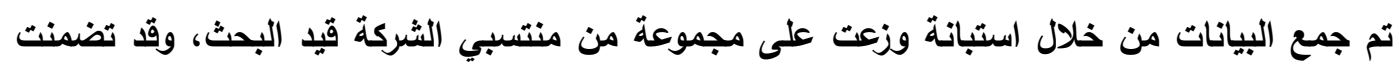

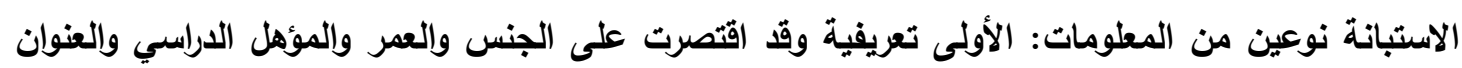

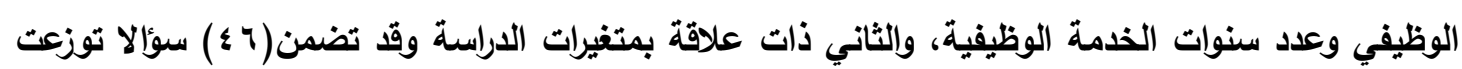
على متغيرات الاراسة وكالآتي:

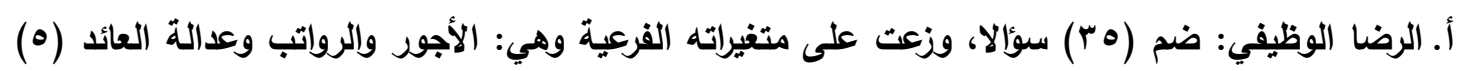

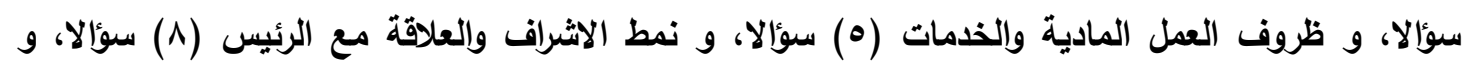

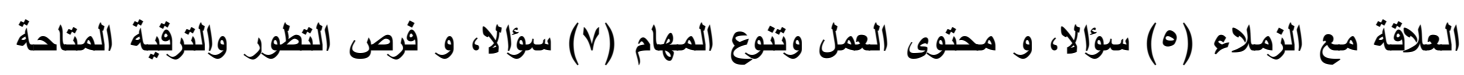
للفرد (0) سؤلا.

ب. الأداء المنظمي: ضم (11) سؤلا وزعت على متفيراته الفرعية وهي: الفاعلية (؛) سؤالا الكفاءة (V) سؤالا.

ت. وقد تم اعداد الاستبانة من المصادر الآتية:

\begin{tabular}{|c|c|}
\hline المصدر & 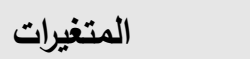 \\
\hline وناس، ^ ^. ب & الرضا الوظيفي \\
\hline 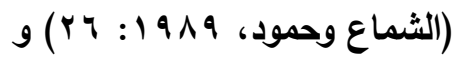 & الأداء المنظمي \\
\hline 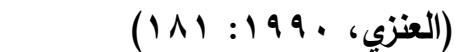 & \\
\hline
\end{tabular}




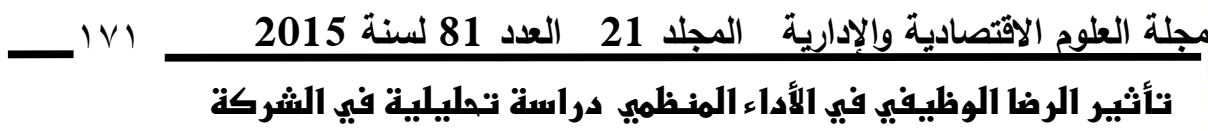

\section{العامة لصناعة البطاريات}

وقت تم استعمال مقياس ليكرت الخماسي الأي يتكون من:

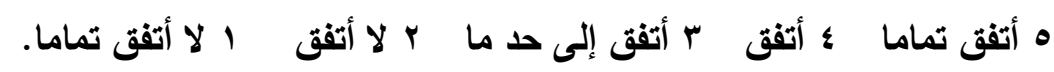

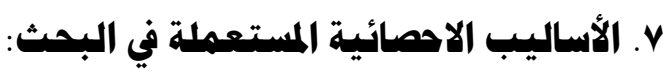

تم توظيف عدد من الأساليب الإحصائية لغرض تحليل البيانات باستخدام البرنامج الاحصائي الجاهز

SPSS.20

أ. معامل ارتباط الرتب لسبيرمان لتحديد اتجاه وقوة العلاقة بين متغيرات الدراسة.

ب. اختبار T لاختبار معنوية العلاقة بين المتغيرات.

ت. معامل الانحدار الخطي البسيط اللامعلمي لاختبار أثر المتغيرات المستقلة في المتغيرات المعتمدة.

ث. اختبار F لاختبار معنوية معامل الانحدار الخطي البسيط.

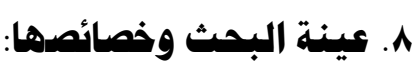

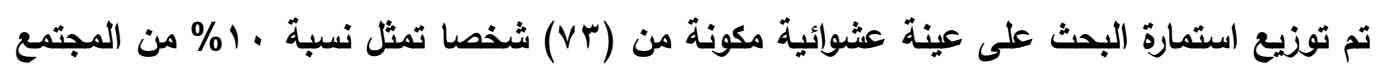

المبحوث، ويوضح الجدول التالي معلومات تعريفية عامة عن العينة.

جدول (1) معلومات عامة عن أفراد العينة

\begin{tabular}{|c|c|c|c|c|c|c|c|c|c|}
\hline \multicolumn{2}{|c|}{ العنوان الوظيفي } & \multicolumn{2}{|c|}{ عدد سنوات الخدمة } & \multicolumn{2}{|c|}{ المؤهل الدراسي } & \multicolumn{2}{|r|}{ العمر - العر } & \multicolumn{2}{|c|}{ الجنس } \\
\hline 19 & ملاحظ & r & أقل من · 1 & $r \varepsilon$ & بكالوريوس & $\varepsilon$ & اقل من هץ & $\leqslant \wedge$ & ذكر \\
\hline rr & ر.ملاحظين & rᄉ & من 1 ـأقل & rq & دبلوم فني & $r$ & هن هـ-أقل & ro & انثى انثى \\
\hline$\varepsilon$ & محاسب & $\{r$ & ها 1 فأكثر & ir & إعدادية فما دون & $\leq \wedge$ & 0 ؛ فأكثر & Vr & \\
\hline rA & م.مدير & Vr & & $v^{r}$ & & Vr & & & المجموع \\
\hline Vr & & & & & & & & & \\
\hline
\end{tabular}

ثانيا: الطروحات النظرية لمتغيرات البحث

I. الرضا الوظيفي Jab Satisfaction

هفهوم الرضا الهظيفي:

أشـار (Magalhaes,1996) الى انه كل شيء كان يبدأ وينتهي من خارج المنظمة، أصبح اليوم كل شيء يبدأ وينتهي من داخلها، سارت هذه الاثارة ردحاً من الزمن أفزز بعدها الفكر الاداري وجهات نظر أخرى

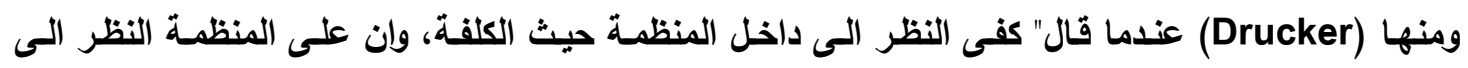

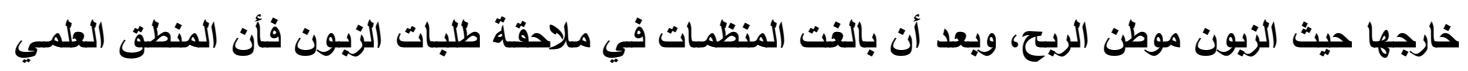

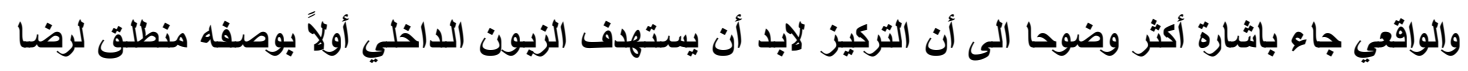

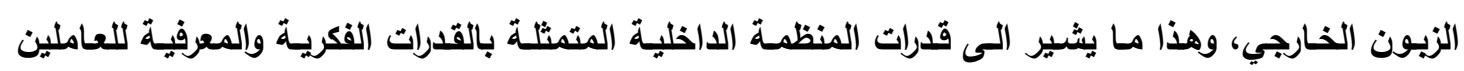
والتي تعد مورداً استراتيجيا تنافسيا قيمـا تقدمه في الأهميـة على رؤوس الأموال الماديـة الأخرى (السـاعدي،

(rs.: : r. I) 


\section{العامة لصناعة البطاريات}

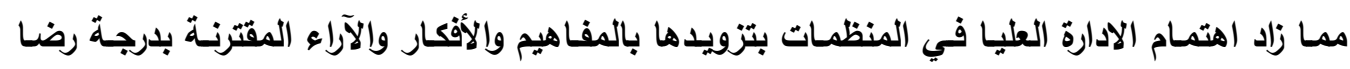

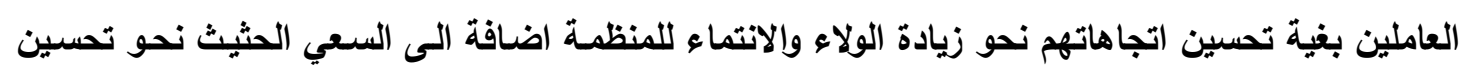
الأجور والرواتب والاشراف وزيادة المتطلبات التدريبية لهم لغرض تحسين وتطوير المهارات الفردية والجماعية

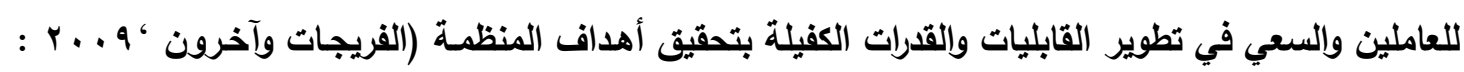

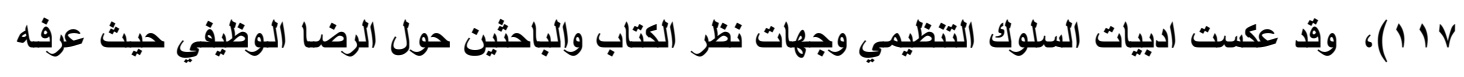

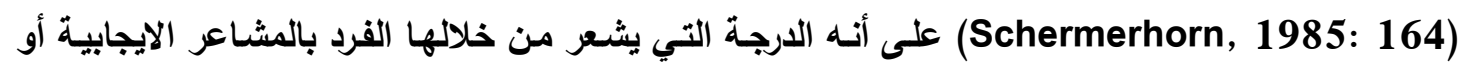
السلبية حول مختلف مجالات العمل، ويرى (Gibson, eat al.; 2003: 105) أن رضا العاملين يمثل ئل

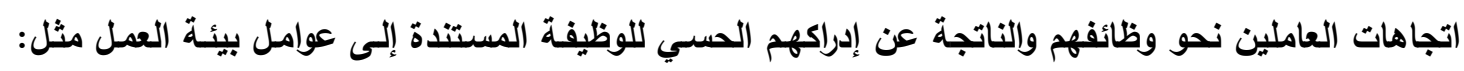

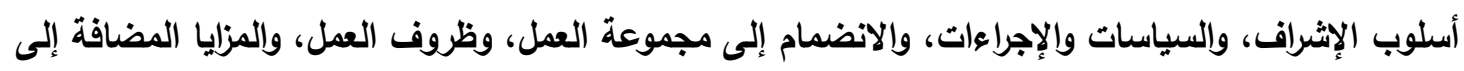

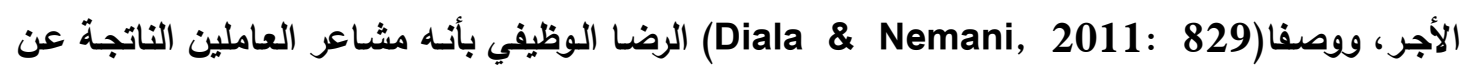

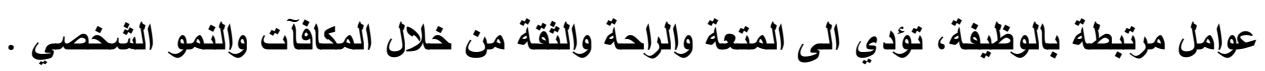

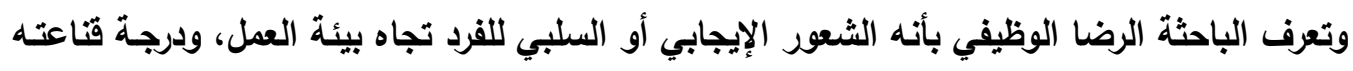

بأن ما يتقاضاه من مكافآت مادية ومعنوية مناسبة لجهوده المبذوله في العمل.

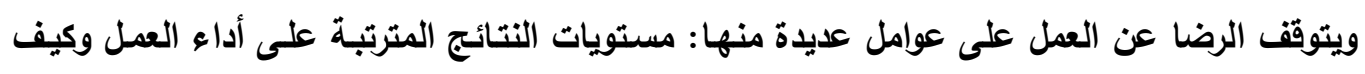

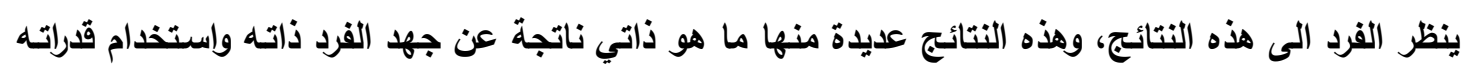

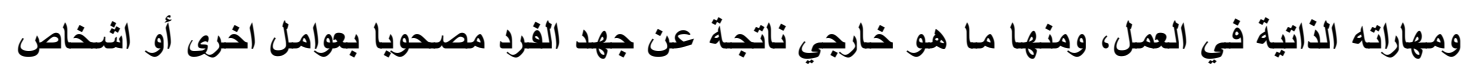
آخرين غير معنيين مباشرة بالعمل نفسه، ويضيف Stoner \& Freeman ان نشأة الفرد واتجاهاته وميوليه

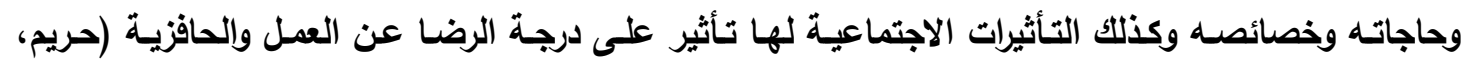

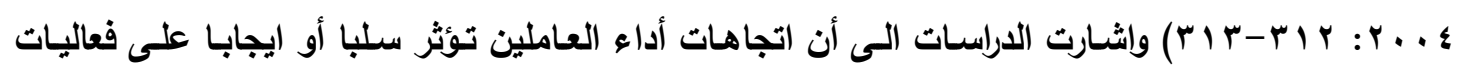

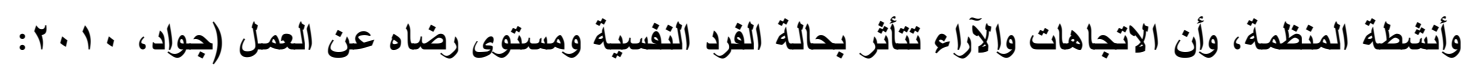

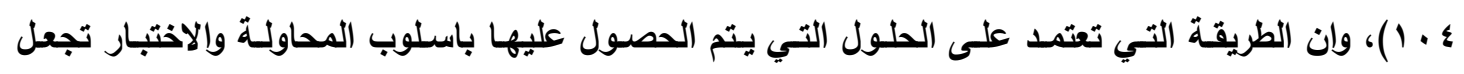

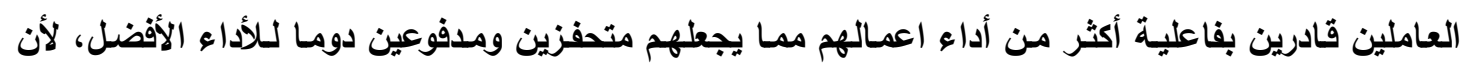

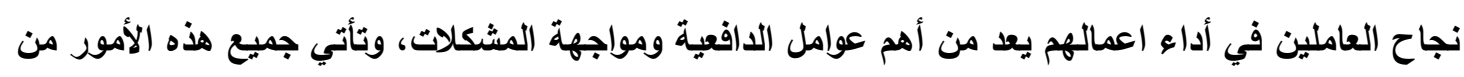

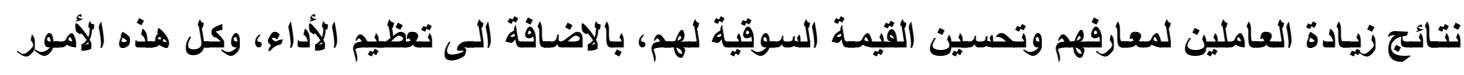

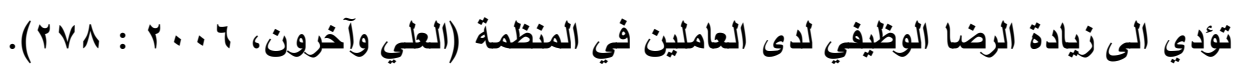




\section{العامة لصناعة البطاريات}

\section{أهمية الرضا الوظليفي:}

يشكل رأس المال البشري أحد المزايا التنافسية الأكثر أهمية والتحدي الأكبر الذي تواجهه المنظمات واذا

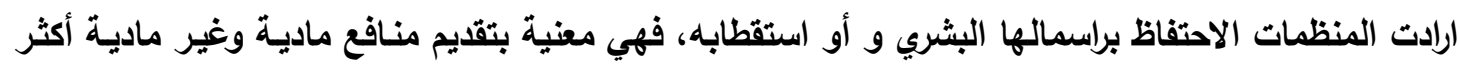

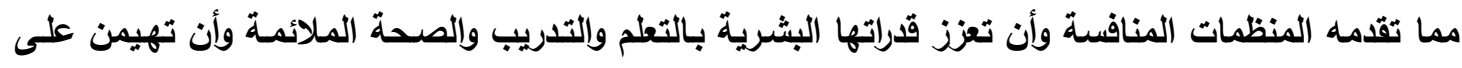

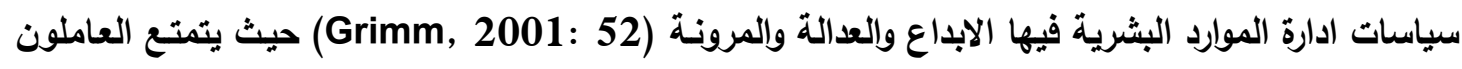
الراضون عن العمل بصحة نفسية وذهنية وجسمية عالية مما ينعكس أثره في زيادة الإنتاجية وتحسين جودة

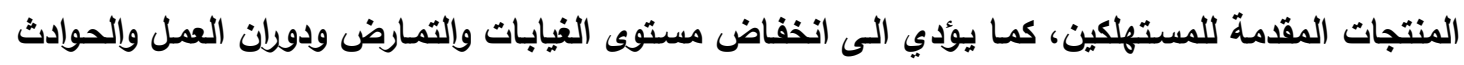

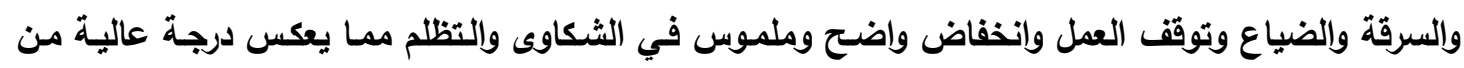

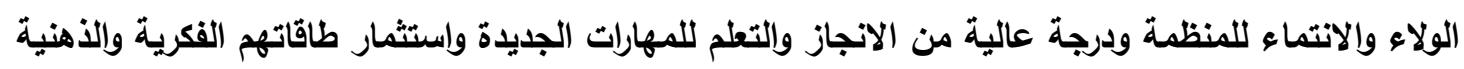

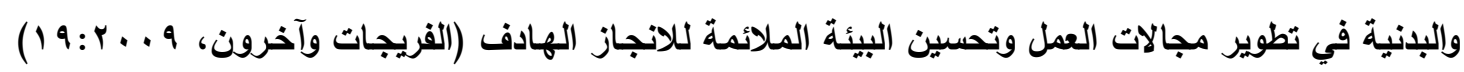
ويرى Beers ان تقليل عدم الرضا لاى المرؤوسين يقلل من مقاومة التغيير لأن العاملين يخشون من التغيير فقدان هويتهم أو الاتصالات والعلاقات الاجتماعية (Hughes, 2009: 614). ويسبب الآثار السلبية التي قد تحدث بسبب عدم الرضا عن العمل فان الادارة يجب أن تهتم بتحسين الرضا

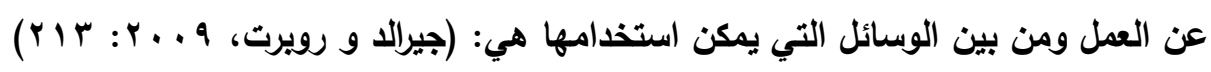

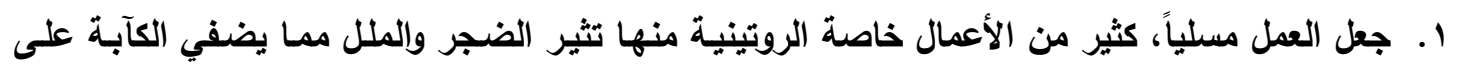
جو العمل ويخلق الاحساس بعدم الرضا، وهناك العديد من الوسائل يمكن استخدامها للتخفيف من ذلتك منها لتهيا الموسيقى ونشر بعض الصور عن المواقف المضككة في العمل وتوزيع بعض الهدايا البسيطة وغيرها.

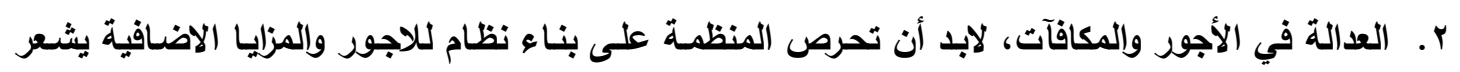
معه الأفراد بالعدل في المعاملة. r. تكليف الأفراد بالأعمال التي تستغرق معظم الاتمامهم يجعهم أكثر رضا عن عملهم.

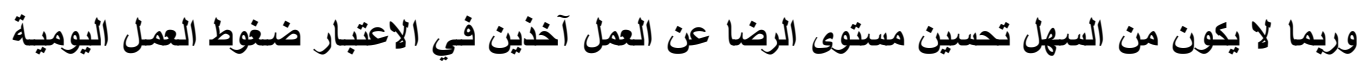

المتزايدة، ولكن نتائج تحسين مستوى رضا العمل، تجعل للجهود المبذولة في هذا المجال قيمة عظيمة.

$$
\text { متغيرا ت الرضا الوظيفي }
$$

تتعلق عناصر الرضـا الـوظيفي بمحتوى الوظيفة والتـي يحقق الفـرد بواسطتها ذاتـه و آمالـه وطموحاتـه

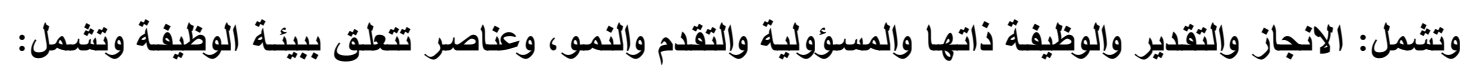

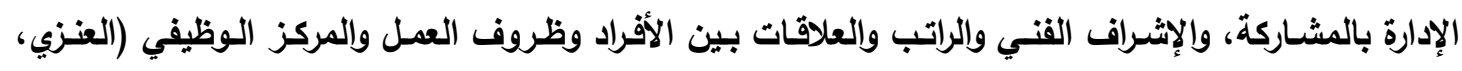

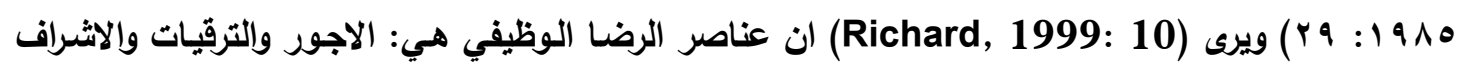

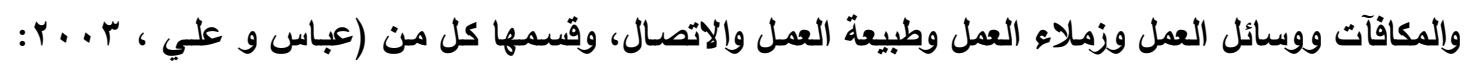
و I A Y l V V

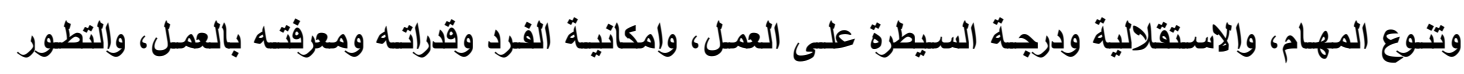

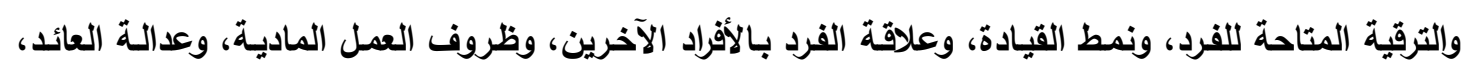

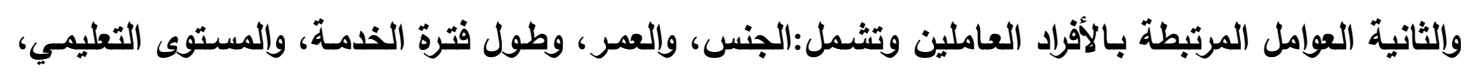

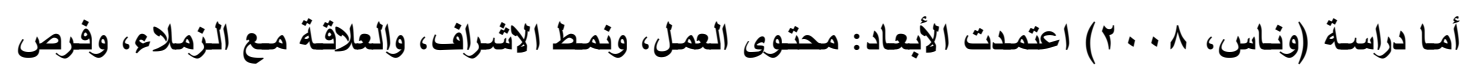




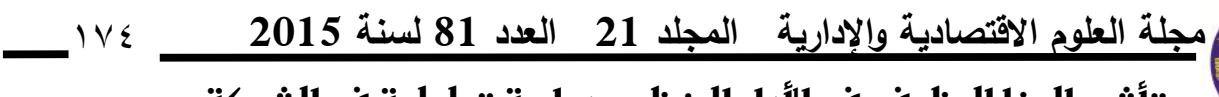

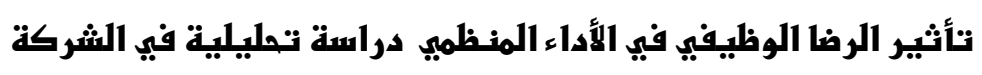

\section{العامة لصناعة البطاريات}

التظور والترقية، وظروف العمل المادية والخدمات، والأجور والرواتب وعدالـة العائد، وقد تبنت الباحثة هذه الأبعاد لملائمتها وأهداف الاراسة وفروف الحالية.

ا. . محتوى العمل: ويمثل ما يتضمنه العمل من مسؤولية وصلاحية ودرجة تنوع في المهام التي يتضمنها

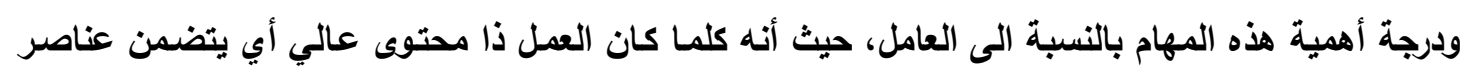

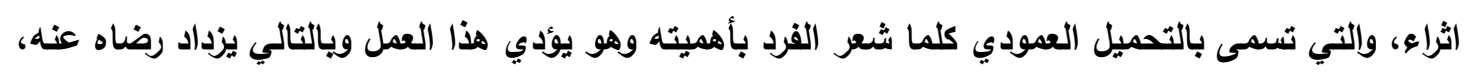

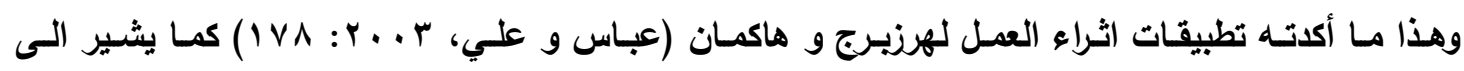

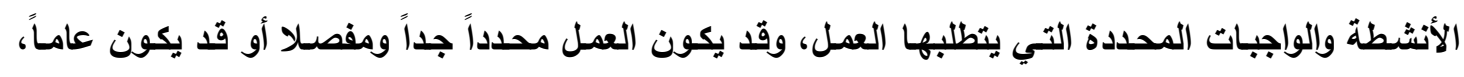

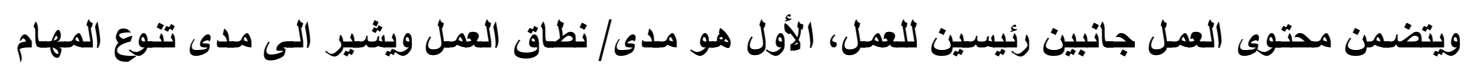

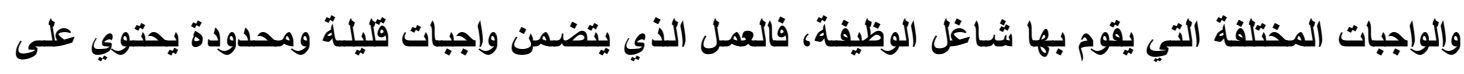
نطاق ضيق ويعتبر العمل روتينيا نمطيا، والثاني عمث العمل ويعني مدى الحرية والاجتهاد والتصرف المسموح

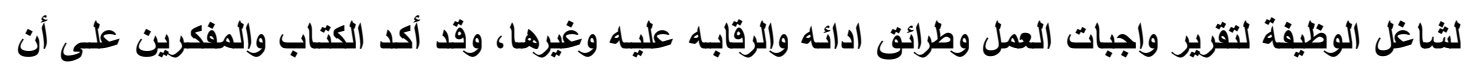

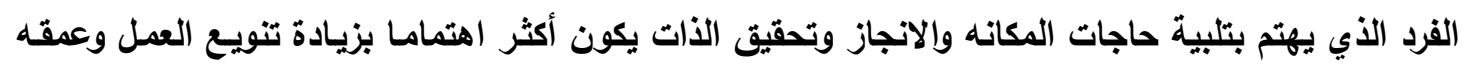

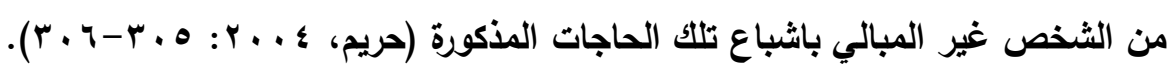
r. ـ نمط الاشراف والعلاقة مع الرئيس: يتوجب على القادة توضيح رؤيته المستقبلية الى المرؤوسبن وتحديد

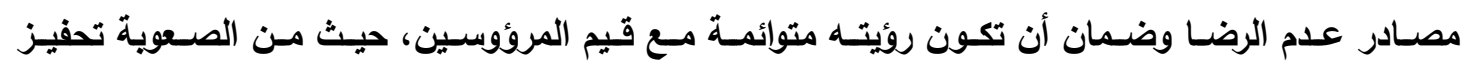
المرؤوسين تجاه روئية غير واضحة، ويتوجب عليه تدريب المرؤوسين حول مـا يتوجب أو لا يتوجب فعلـه،

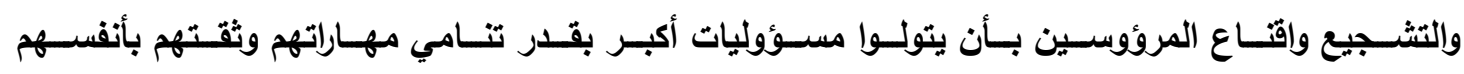

.(Hughes, 2009: 645)

r. العلاقة مع الزملاء: يطلق عليها البعض القابلية على المخالطة، وتعني في مجال السلوك التنظيمي رغبة

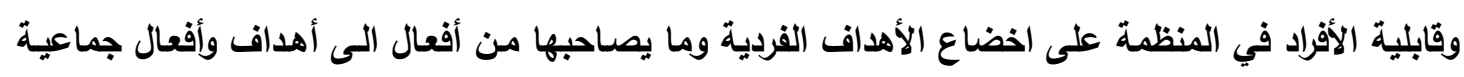

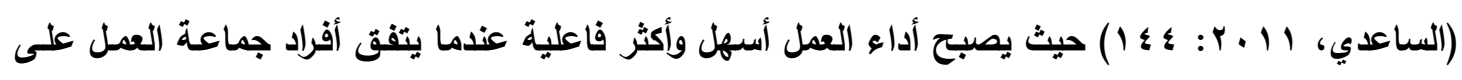
بعض الأسـاليب لانجـاز واجباتهم، ومـن الأمسور التي تنظم التفاعل السـلوكي بين الأعضـاء وجود اشتـارات

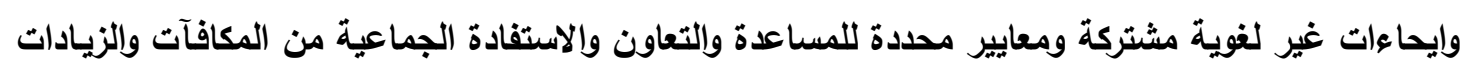
في الأجور وغيرها، وان معايير التفاعل السلوكي تسهل على الجماعة حل ما ينشأ بين أعضائها من مشكلات

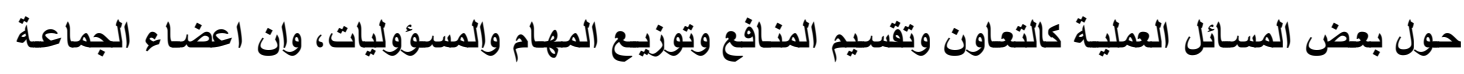

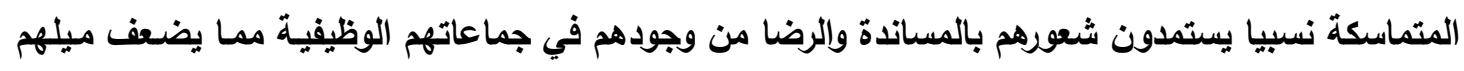

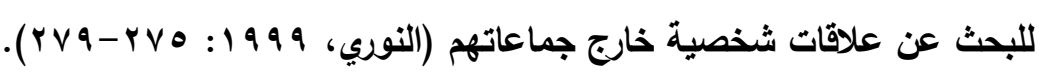

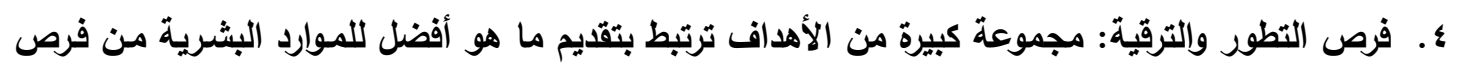

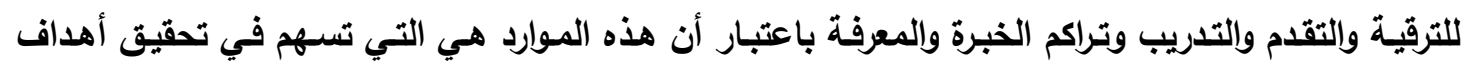

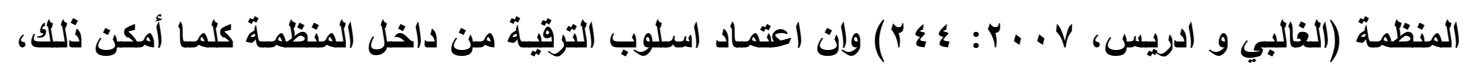

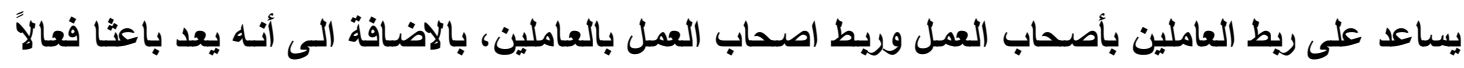

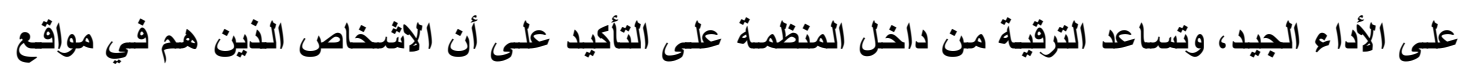

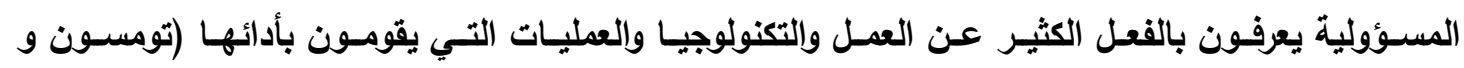




\section{العامة لصناعة البطاريات}

هـ ـ ظروف العمل الماديـة والخدمات: تهدف الخدمات المتعلقة بالوظيفة تسيير مهمـة العاملين في أداء

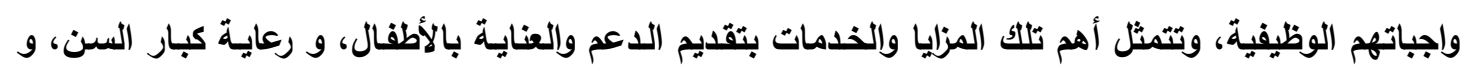

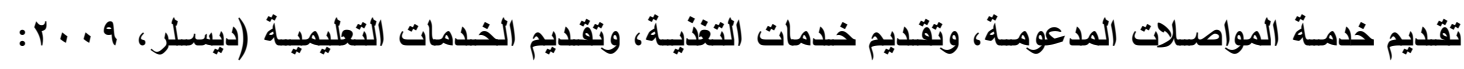

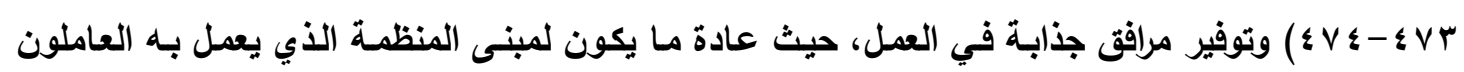

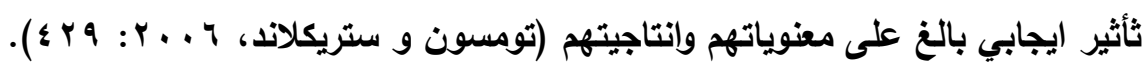

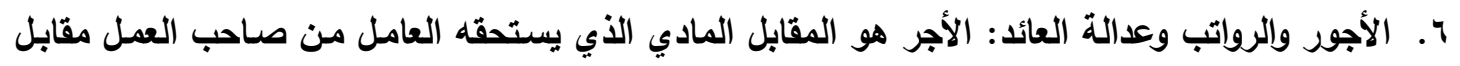

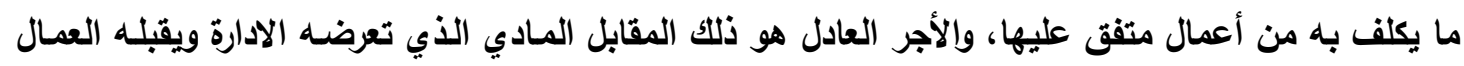

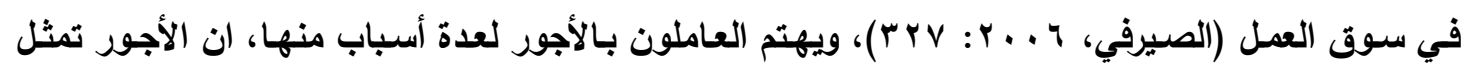

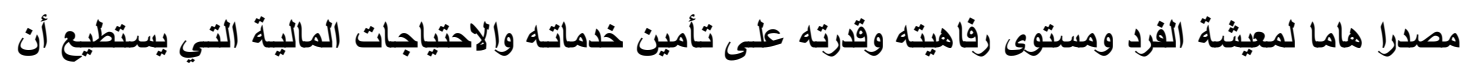

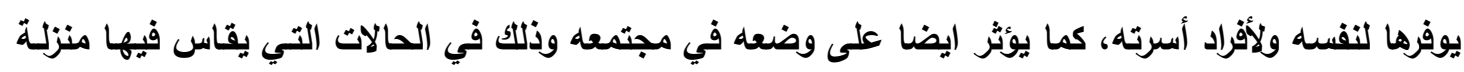

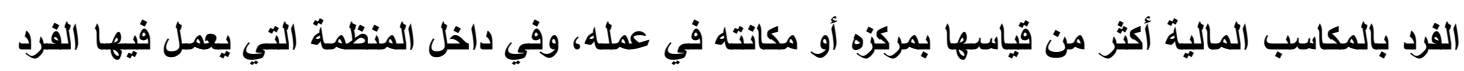

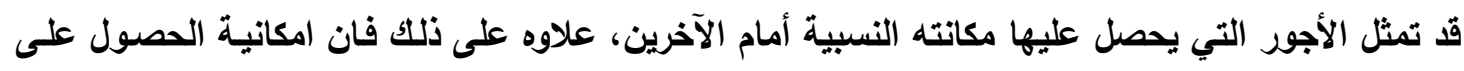

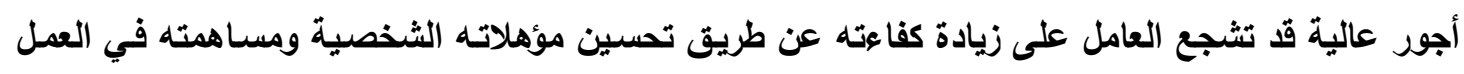

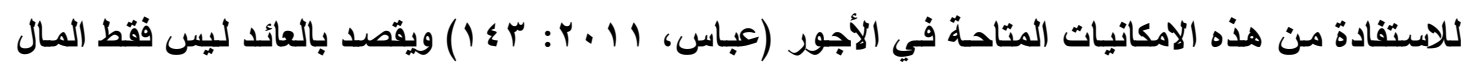

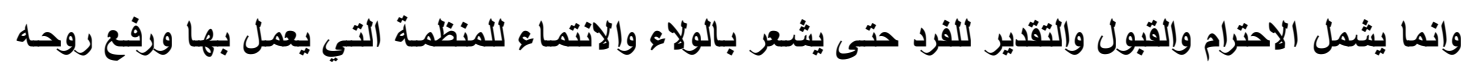

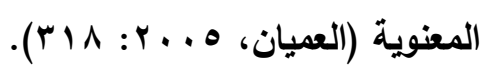

\section{r. الأداء المنظمي: Organizational Performance}

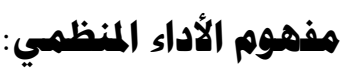

عرف كل من (Zahar \& Pearce, 1989) الأداء المنظمي على أنـه النتائج المتحققة نتيجة تفاعل

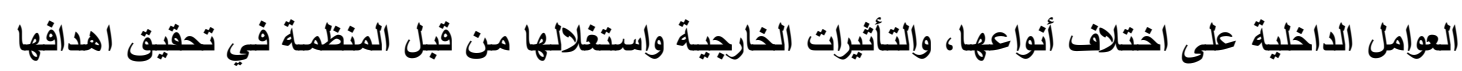

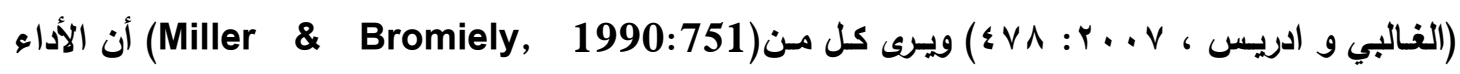

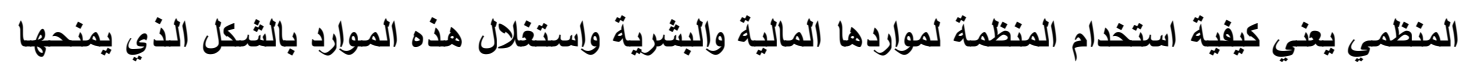
القدرة على تحقيق الأهداف المرجوه التي تسعى الى تحقيقها، ويضيف Daft عنصري الكفاءة والفاعلية في تعريفه، فالأداء المنظمي يعني قدرة المنظمة على تحقيق أهدافها من خلال استعمال الموارد المتاحة بطريقة

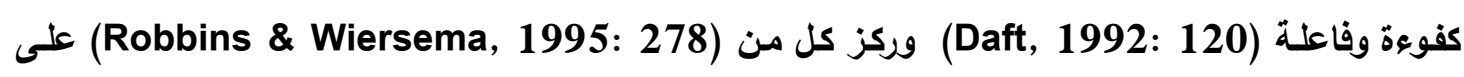
الميزة التنافسية، فالأداء المنظمي يعني الاستعمال الأمثل لموارد المنظمـة المادية والبشرية المتاحة لتحقيق أهدافها طويلة الأمد للمحافظة على ميزتها التنافسية، وربط (Schermerhor, et al; 2000: 26)

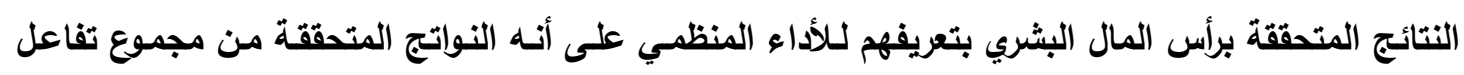
النشاطات المنظمية لمواردها والمتمثل بقدرة المنظمة في الحصول على أفراد جيدين والحفاظ على نتائج جيدة، ووصفه كل من (Wheelen \& Hunger, 2004: 243) على أنه النتيجة النهائية لأنشطة وفعاليات المنظمة، وفي السياق ذاته عرفه (Molina, et all; 2010: 389) هو الحلقة الأخيرة التي ترغب المنظمة

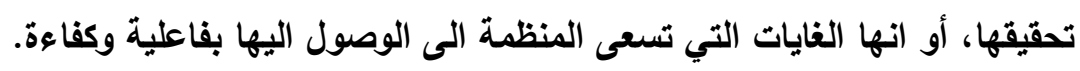




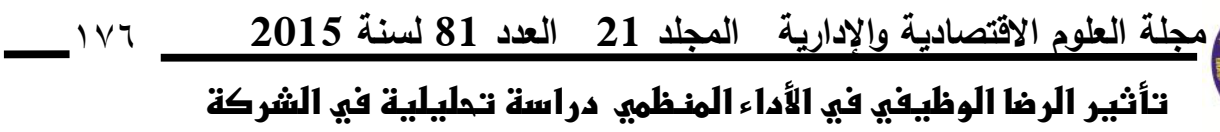

\section{العامة لصناعة البطاريات}

وتعرف الباحثـة الأداء المنظمـي بأنـهـ قدرة المنظمـة على اسـتذام مواردهـا بكفـاءه لتحقيـق النتـائج

المرغوية، والقادرة على مواجهة تحديات البقاء في بيئة المنافسة في مجال عملها.

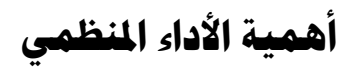

يمثل الأداء مركز الادارة الاستراتيجية، حيث أن الأداء يمثل اختبارا زمنيا للاستراتيجية المتبعة من

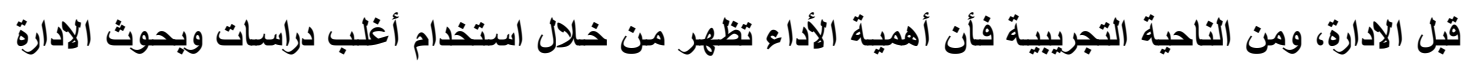

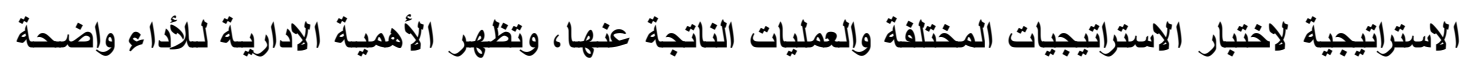

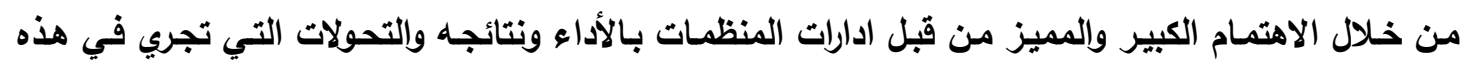

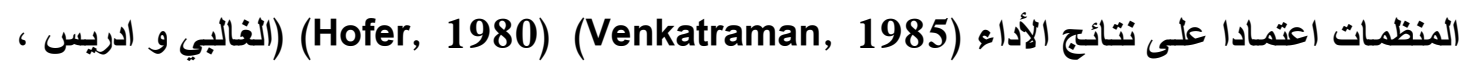

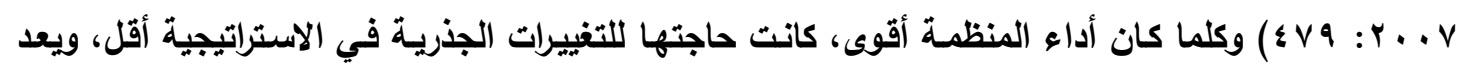

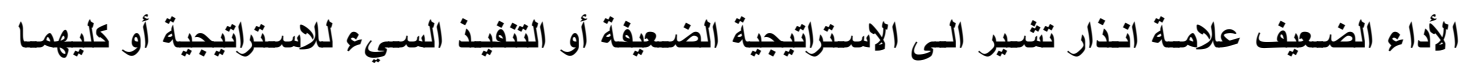

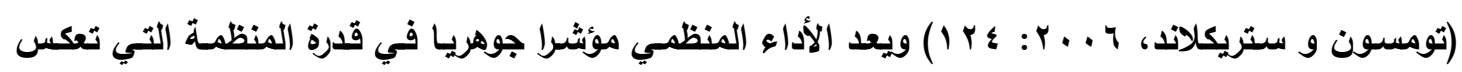
مدى النجاح الذي تحققه في استثمار الموارد الماديـة والبثرية والفتية والمعلوماتيـة المتاحة لها (الخطيب،

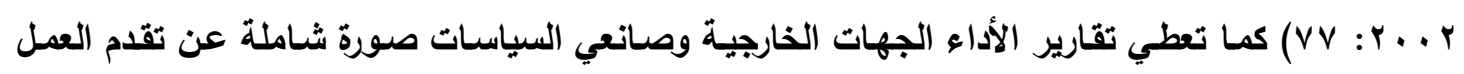

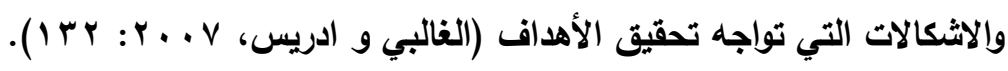
هقاييس الأداء المنظمي:

يواجه مقاييس الأداء المنظمي تحديات عديدة تتمثل في تباين المفهوم ومؤثثرات قياسـه تبعا لتباين

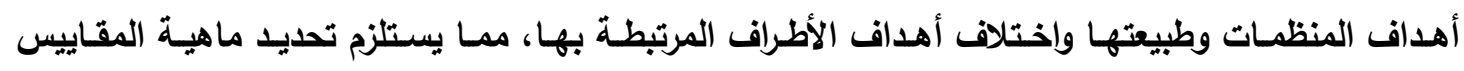
المناسبة التي يمكن استخدامها في قياس الأداء ومصدر المعلومات المعتمده في القياس وكيفية دمـج قياسات

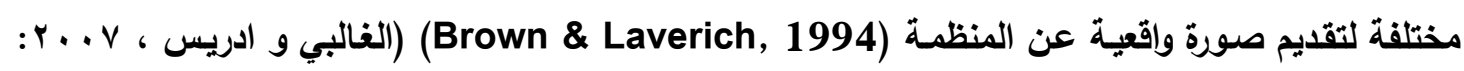

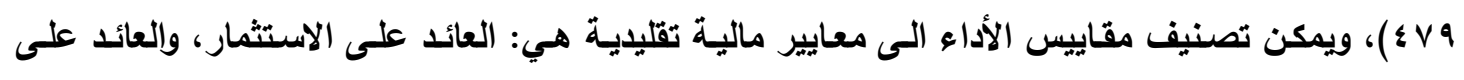

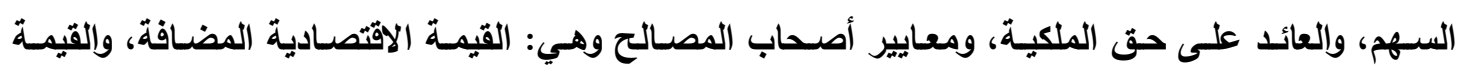

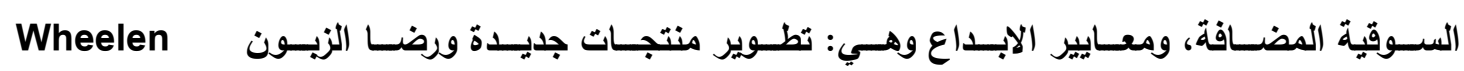
(\&hunger,2004: 243)

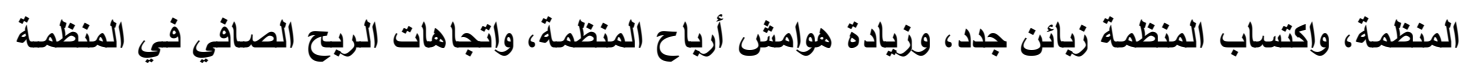
وعائد الاستثمار والقيمة المضافة، ومدى قدرة المنظمة على اجراء تحسين مستمر في مقابيس الأداء الداخلي

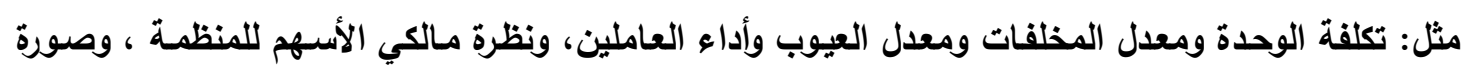

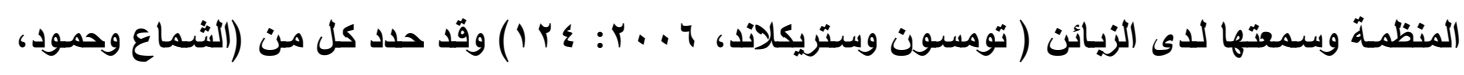

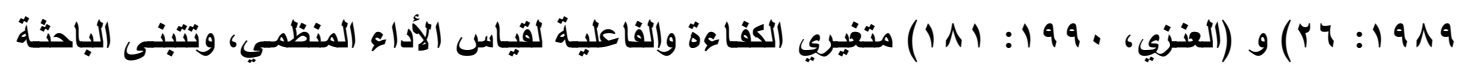
هذا المقياس لملائمته واهداف الدراسة الحالية. 


\section{العامة لصناعة البطاريات}

الكناsة: Efficiency

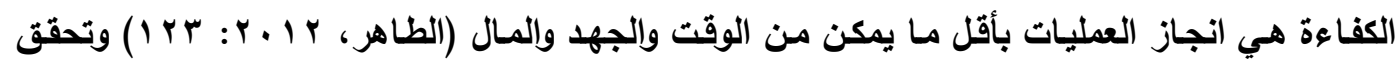

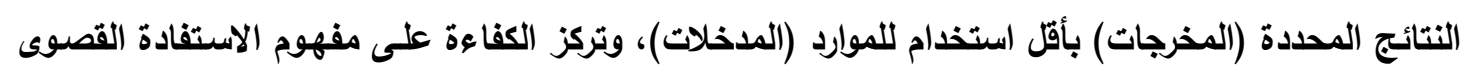

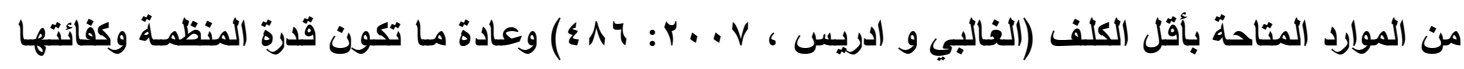

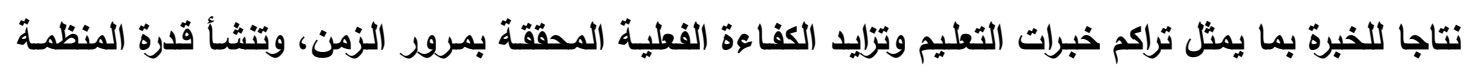
نتيجة للجهود الدائبة لتطوير قدرة المنظمة على القيام بأمر ما، وتستدعي مثل هذه الجهود، تحديد الأثخاص

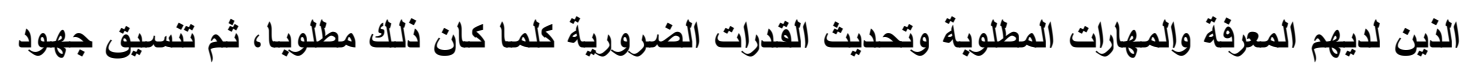

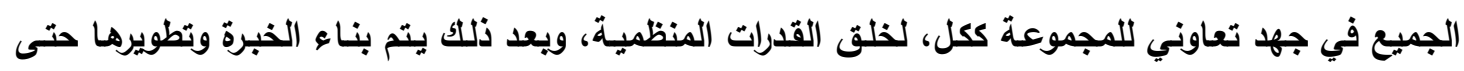
تصل المنظمة الى مستوى جيذ من القدرة والكفاءة في القيام بالأنثطة المطلويـة ويتكلفة مقبولة بحيث تبدأ

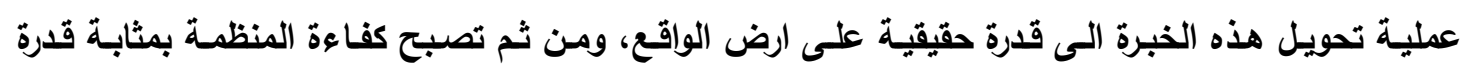

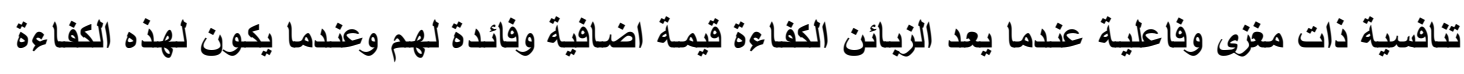

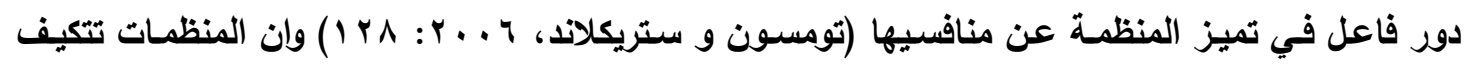

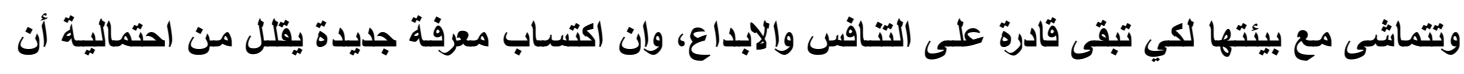

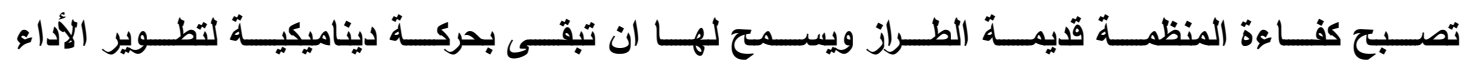

.(Morales, etal; 2006: 22)

الفاعلية : Effectiveness

يتعلق مصطلح الفاعلية بتحقيق الأهداف، كما أنه يعني التأكد من ان استخدام الموارد المتاحة قد أدى الدى

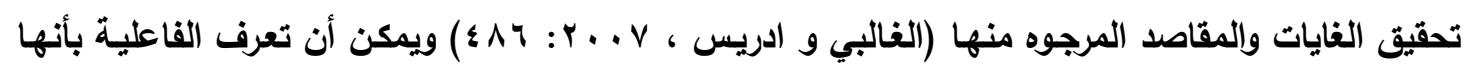

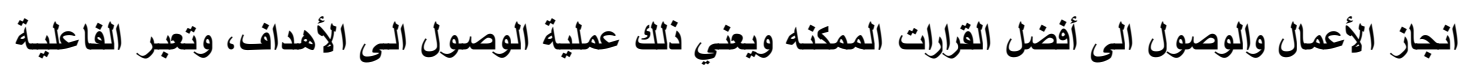

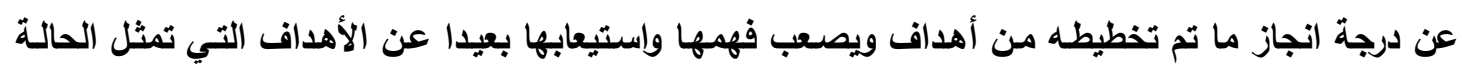

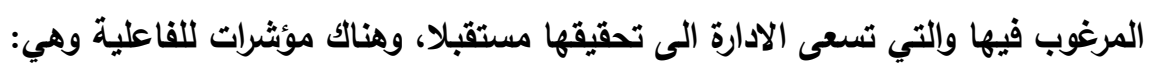

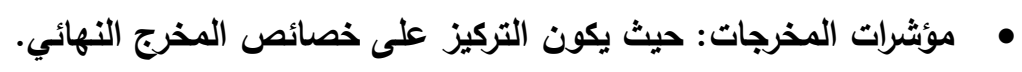
• مؤشرات العمليات: والتي تركز على جودة وكمية الأنشطة التي تؤدى من اجل انجل انجاز المخرجات.

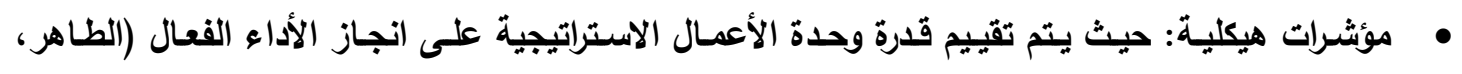

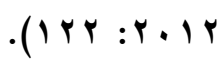

وينظر (Shipper \& White, 1983) الى قياس الفاعلية التظيمية من منطلقين داخلي وخارجي،

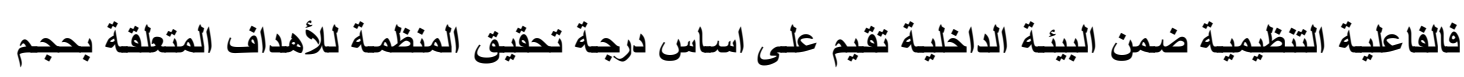
المبيعات، والحصة السوقية، والأرباح، أما ضمن البيئة الخارجية فأن فاعلية المنظمة تقاس على أساس قوتهاتها

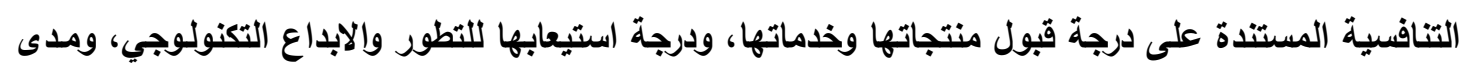

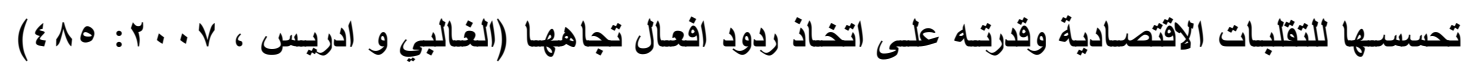

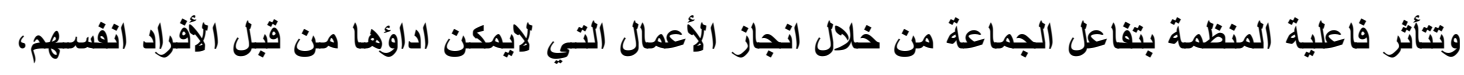

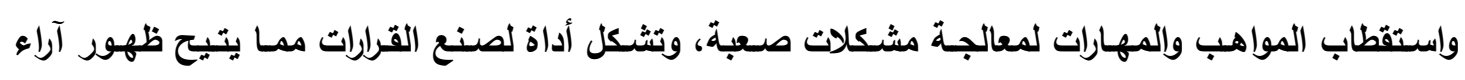
عديدة، وتسهيل عملية تغيير سياسـات واجراءات المنظمة، وتزيل من استقرار المنظمـة عن طريق نقل القيم 


\section{العامة لصناعة البطاريات}

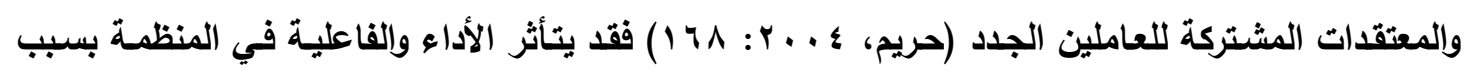

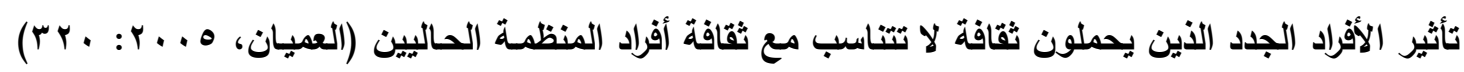

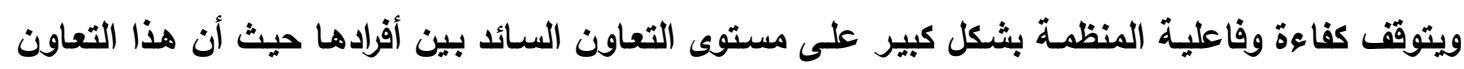

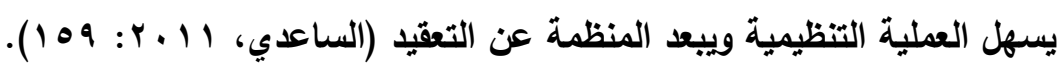

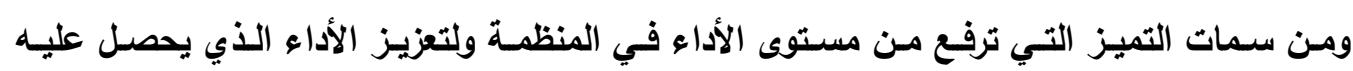

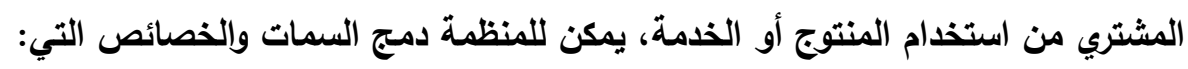

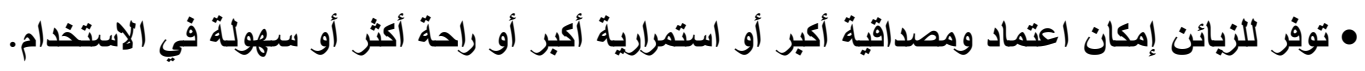

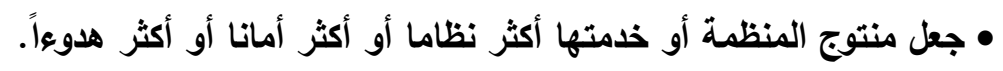
• تقديم صيانة مجانية أكثر شمولا من العلامات التجارية للمنافسين الأخرين.

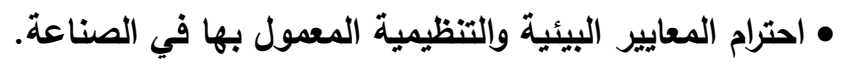

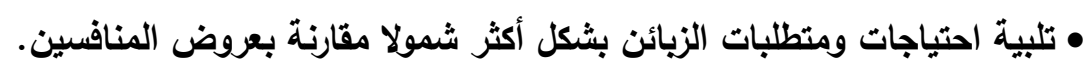

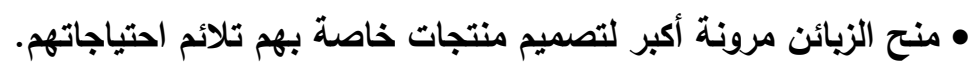

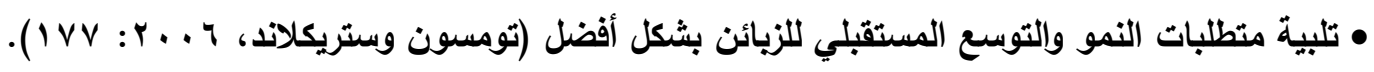

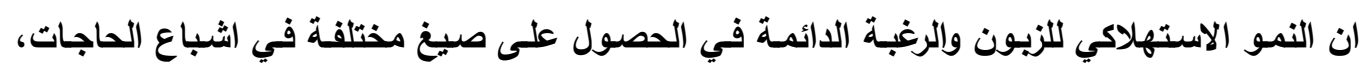

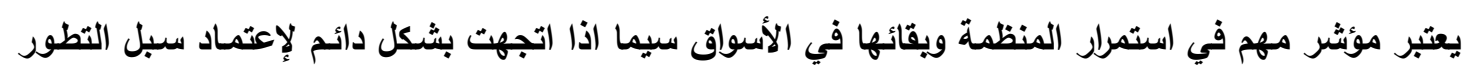

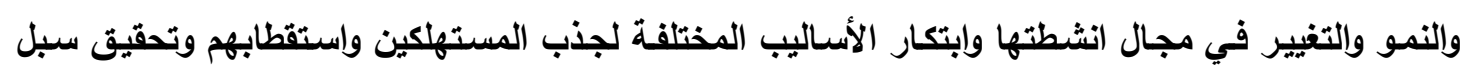

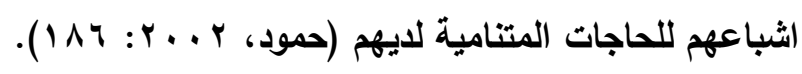
ثالثا: الجانب العهمبي اختبار النموذج البحث وفرضياته:

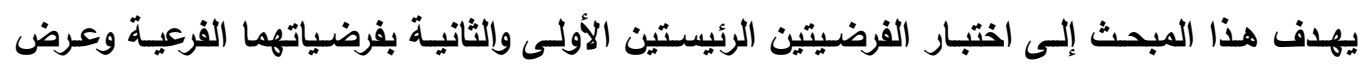

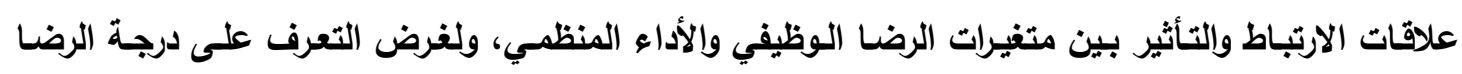
الوظيفي في الشركة قيد الاراسـة، تم استخراج الوسط الحسـابي المرجح والانحراف المعياري لكل متغيراتها وكانت النتائج كالآتي:

جدول (ץ) الوسط الحسابي المرجح والاتحراف المعياري لأبعاد الرضا الوظيفي

\begin{tabular}{|c|c|c|c|}
\hline الانحراف المعياري & الوسط الحسابي المرجح & أبعاد الرضا الوظيفي & $ت$ \\
\hline .947 & r.Aro & الأجور والرواتب وعدالة العائد & 1 \\
\hline$\because v \bullet \wedge$ & $r .1 \wedge 9$ & ظروف العمل المادية والخدمات & r \\
\hline$\cdot .7 \cdot 1$ & r.09r & نمط الأشراف والعلاقة مع الرئيس & $r$ \\
\hline. .479 & r.v & العلاقة مع الزملاء & $\varepsilon$ \\
\hline. $.7 \mathrm{rv}$ & $r .7 \leq 1$ & محتوى العمل وتنوع المهام & $\bullet$ \\
\hline. .797 & r.l r. & فرص التطور والترقية المتاحة للفرد & 7 \\
\hline. $.0 Y V$ & $r .19$. & الرضا الوظيفي & \\
\hline
\end{tabular}




\section{العامة لصناعة البطاريات}

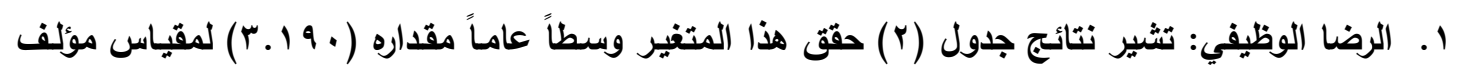

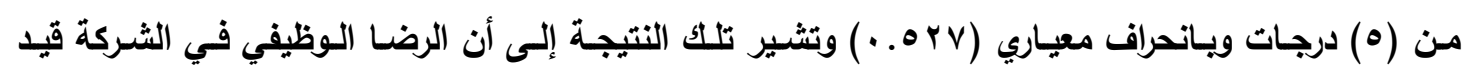

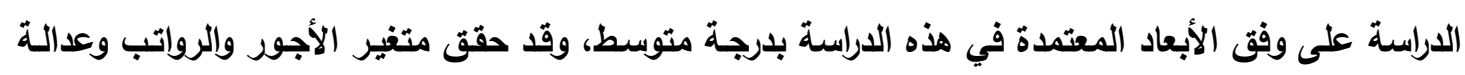

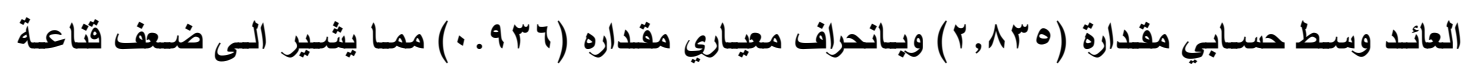

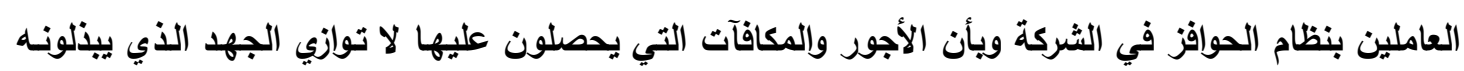

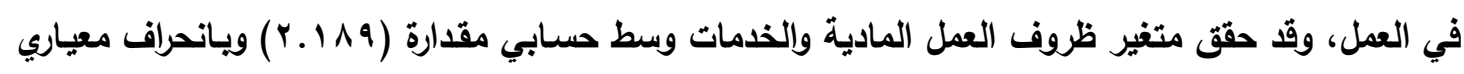

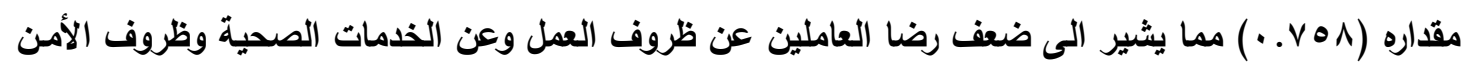

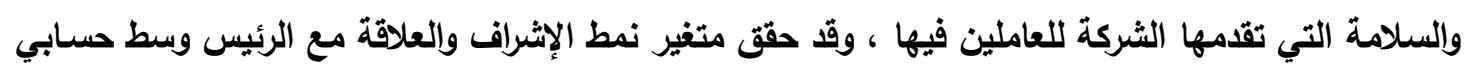

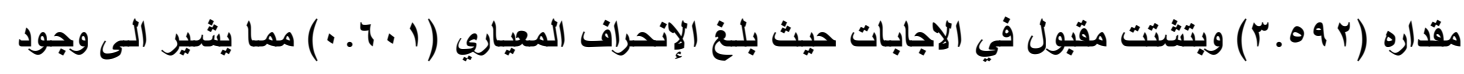

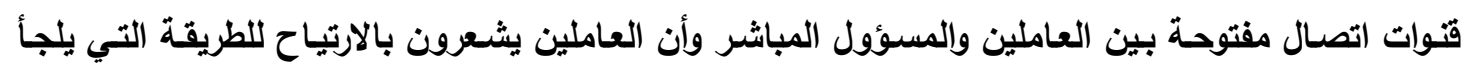

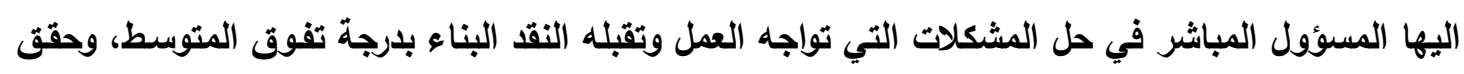

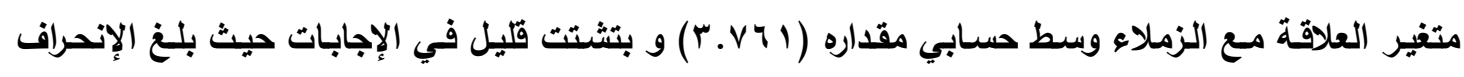

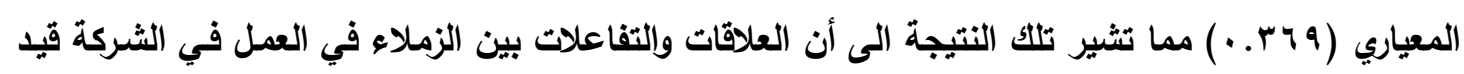
الدراسة بلرجة جيدة وأن العاملين يتبادلون الخبرات فيما بينهز. وقد حقق متغير محتوى العمل وتنوع المهام وسط حسابي مقداره ( أ ؟.ب) بانحراف معياري مقداره

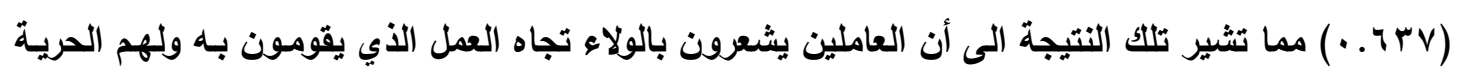

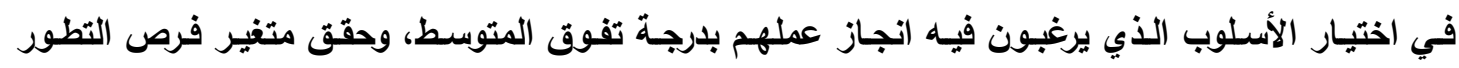

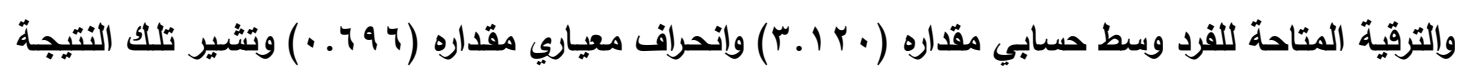

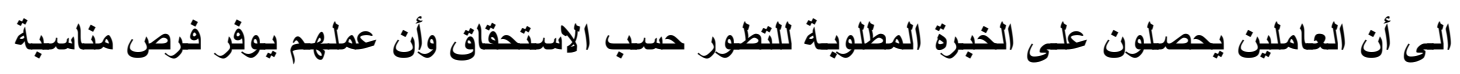

لتطوير مهاراتهم بلرجة متوسط.

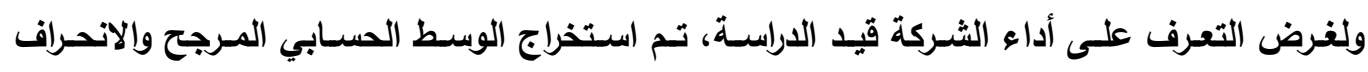
المعياري لمتغيراته وكانت النتائج كالآتي:

جدول (r) الوسط الحسابي المرجح والانحراف المعياري لأبعاد الأداء المنظمي

\begin{tabular}{|c|c|c|c|}
\hline الانحراف المعياري & الوسط الحسابي المرجح & أبعاد الأداء المنظمي & $\Xi$ \\
\hline $.7 \vee \wedge$ & $r . \varepsilon \otimes \wedge$ & الفاعلية & 1 \\
\hline$\therefore \leqslant \Lambda$. & r.rio & الكفاءة & r \\
\hline .011 & r.AAV & الأداء المنظمي & \\
\hline
\end{tabular}

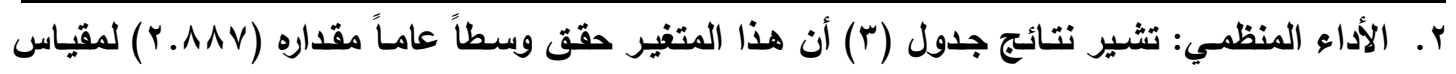

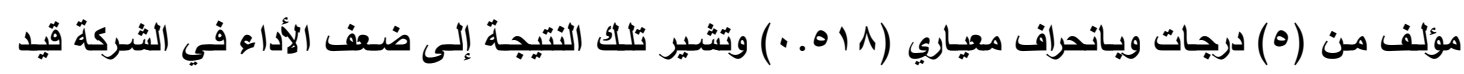

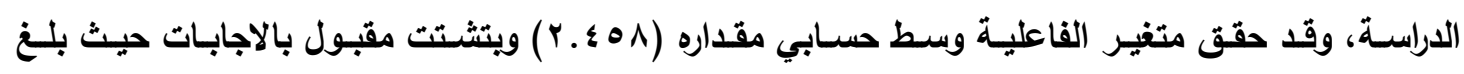

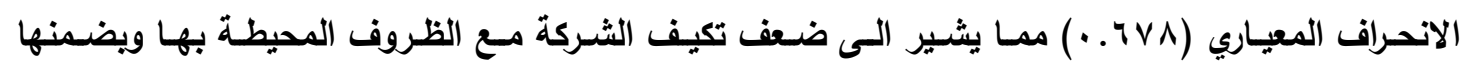

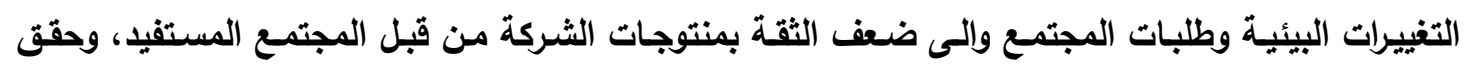




\section{العامة لصناعة البطاريات}

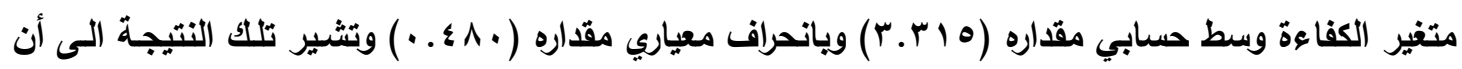

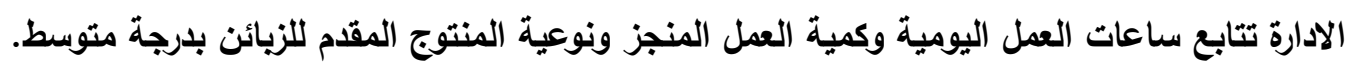

اختبار الفرضية الرئيسة الأولى والفرضيات المتفرعة عنها:

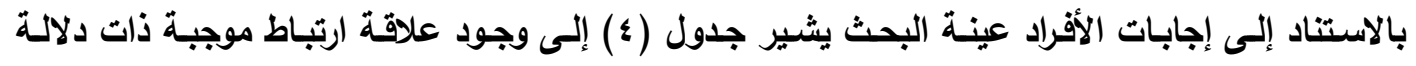

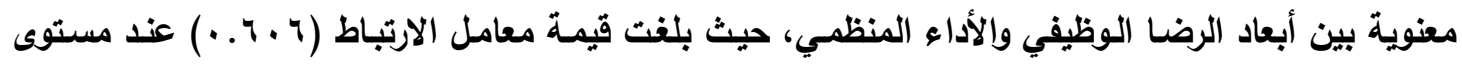

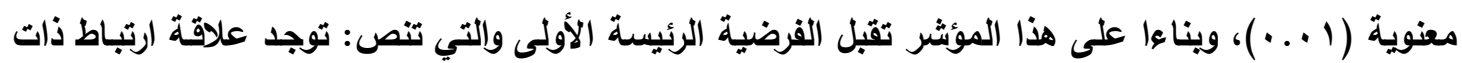

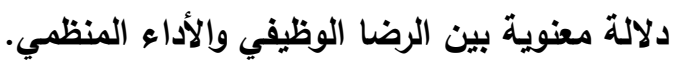
جدول(ء ) علاقة الارتباط بين الرضا الوظيفي والأداء المنظمي

\begin{tabular}{|c|c|c|c|}
\hline قبول أو عدم قبول & الدلالة & معامل الارتباط & المتغيرات \\
\hline قبول & معنوية & $* * .7 .7$ & الرضا الوظيفي والأداء المنظمي \\
\hline
\end{tabular}

ومن أجل التحقق من نتائج العلاقات لكل من متغيرات الرضا الوظيفي و الأداء المنظمي يوضح جدول(ه) تفاصيل هذه النتائج. جدول (ه) علاقات الارتباط بين متغيرات الرضا الوظيفي و الأداء المنظمي

\begin{tabular}{|c|c|c|c|}
\hline قبول الفرضية أو عدم & الدلالة & معامل الارتباط & 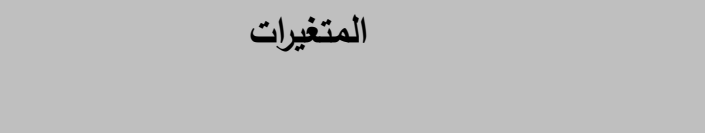 \\
\hline 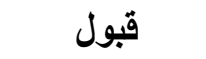 & معنوية & $* * . .0 \vee 9$ & الأجور والرواتب وعدالة العائد والأداء المنظمي \\
\hline 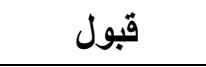 & 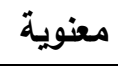 & $* * \ldots \leqslant \wedge 1$ & ظروف العمل المادية والخدمات والأداء المنظمي \\
\hline ق قبول & معنوية & $* * . . \leqslant \varepsilon 9$ & نمط الإشراف والعلاقة مع الرئيس والأداء المنظمي \\
\hline 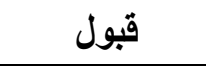 & 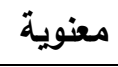 & $* * \ldots$ *.$\leqslant$. & العلاقة مـع الزملاء والأداء المنظمي \\
\hline قبول & 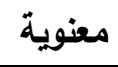 & $* * \ldots \leqslant r$ & محتوى العمل وتنوع المهام والأداء المنظمي \\
\hline 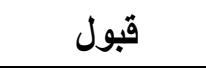 & معنوية & $* * .79 \mu$ & فرص التطور والترقية المتاحة للفرد والأداء المنظمي \\
\hline & & & 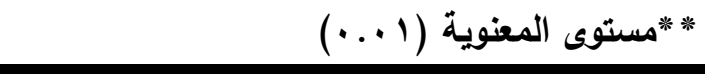 \\
\hline
\end{tabular}

ا. الأجور والرواتب وعدالة العائد: يشير جدول (0) إلى وجود علاقة ارتباط موجبة ذات دلالة معنوية بين

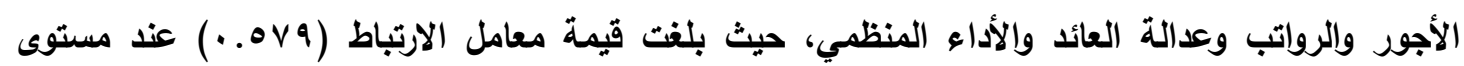

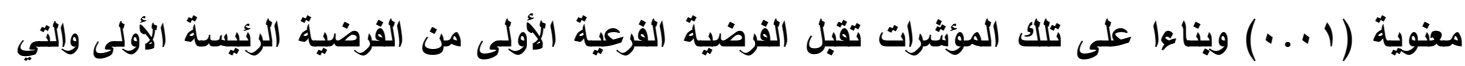
تنص: توجد علاقة ارتباط ذات دلالة معنوية بين الأجور والرواتب وعدالة العائد والأداء المنظمي.

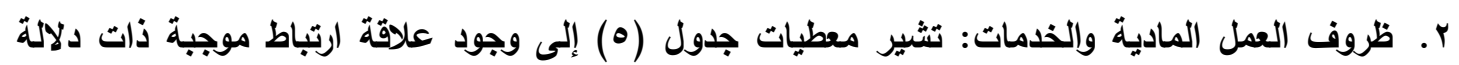

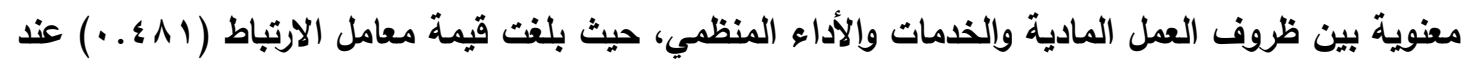

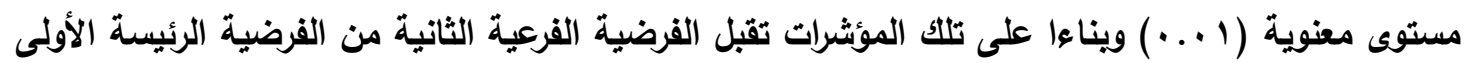
والتي تنص: توجد علاقة ارتباط ذات دلالة معنوية بين ظروف العمل المادية والخدمات والأداء المنظمي. 


\section{العامة لصناعة البطاريات}

r. نمط الاشراف والعلاقة مع الرئيس: تثير معطيات جدول (0) إلى وجود علاقة ارتباط موجبة ذات دلالة

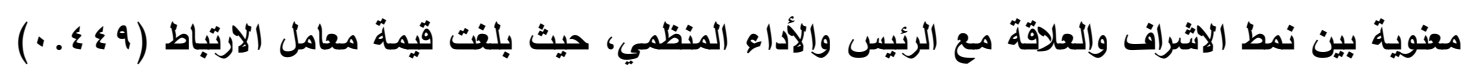

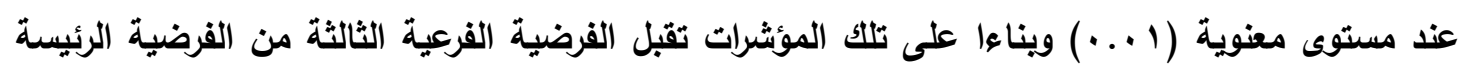
الأولى والتي تنص: توجد علاقة ارتباط ذات دلالة معنوية بين نمط الاثراف والعلاقة مع الرئيس والأداء

المنظمي. ء. العلاقة مع الزملاء: تثير معطيات جدول (ه) إلى وجود علاقة ارتباط موجبة ذات دلالة معنوية بين

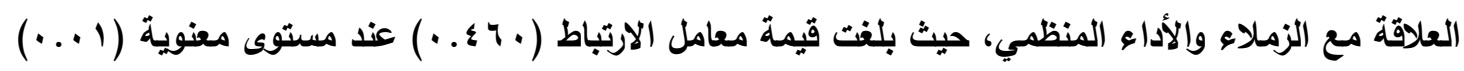

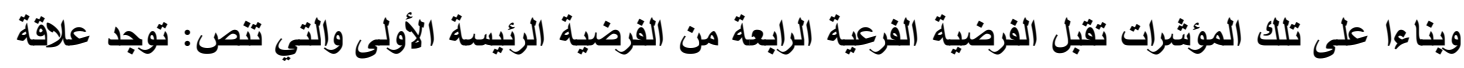
ارتباط ذات دلالة معنوية بين العلاقة مع الزملاء والأداء المنظمي.

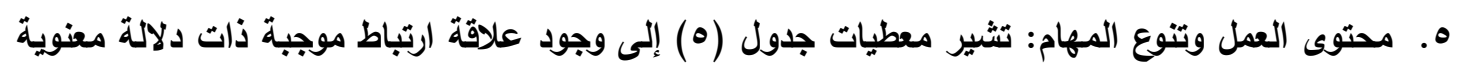

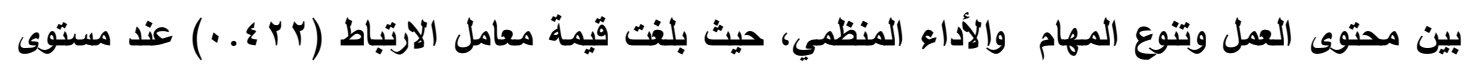
معنوية (1 + . •) ويناءا على تلك المؤثرات تقبل الفرضية الفرعية الخامسة من الفرضية الرئيسة الأولى والتي تنص: توجد علاقة ارتباط ذات دلالة معنوية بين محتوى العمل وتنوع المهام والأداء المنظمي.

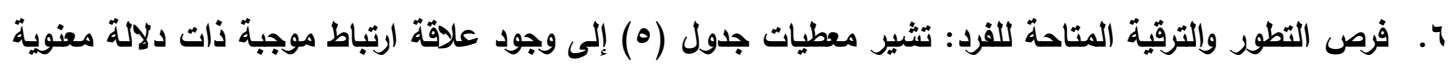

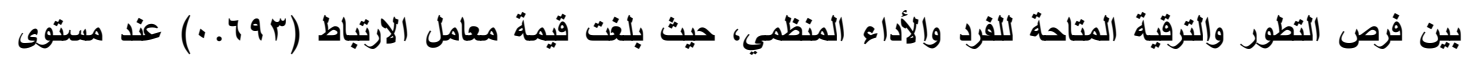

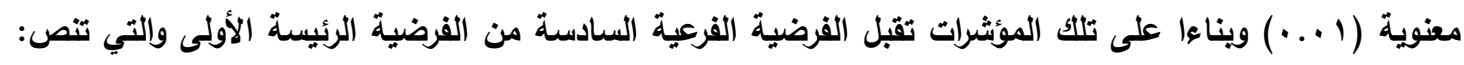
توجد علاقة ارتباط ذات دلالة معنوية بين فرص التطور والترقية المتاحة للقرد والأداء المنظمي.

\section{اختبار الفرضية الرئيسة الثانية والفرضيات المتفرعة عنها:}

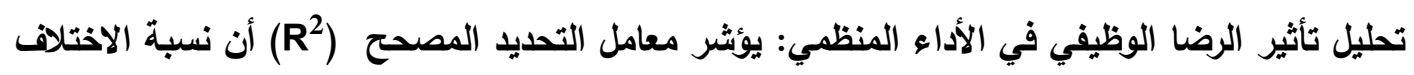

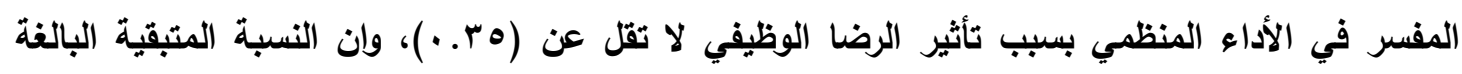

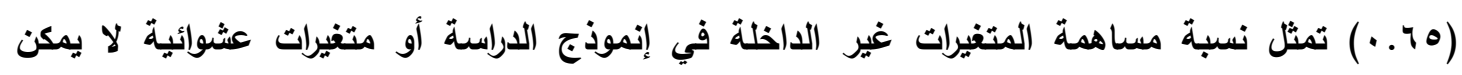

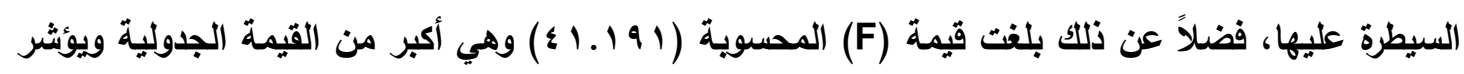

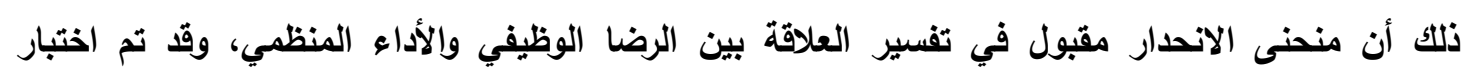

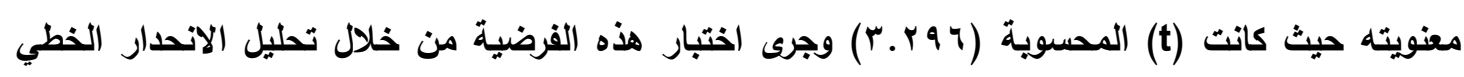

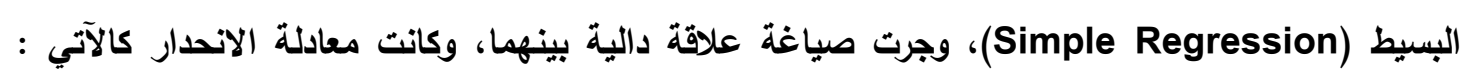

$$
\mathbf{Y}=\boldsymbol{\&}+\mathbf{B x}
$$

حيث يمثل Y المتغير المعتمد (الأداء المنظمي)، و XX المتغير المستقل (الرضا الوظيفي) $Y=0.988+0.595 X$

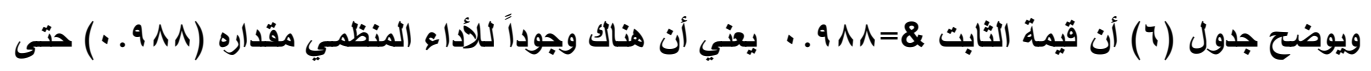

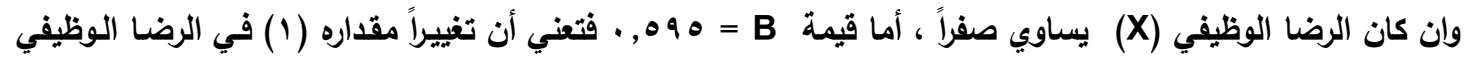

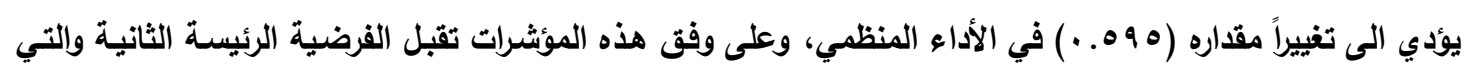

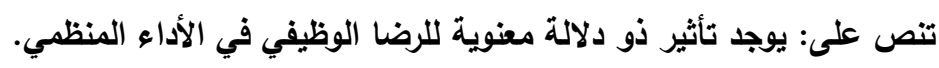




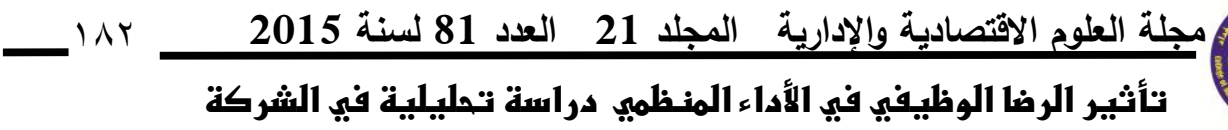

\section{العامة لصناعة البطاريات}

\begin{tabular}{|c|c|c|c|c|c|c|}
\hline B & $T$ & Sig & F & Sig & R المصح & المتغيرات \\
\hline $\begin{array}{l}1.9 v 9 \\
\text { a.r. }\end{array}$ & Ir.rAr & $\cdots$ & एo.v9 & $\cdots$ & דצr. & الأجنور والرواتب وعدالـة العائد في الأداء \\
\hline $\begin{array}{l}\text { r.1rA } \\
. . r Y A\end{array}$ & Ir.IVT & $\cdots$ & rl.ror & $\cdots$ & DTr. & المنظمي ل ظروف العمل الماديـة والذذمات في الأداء \\
\hline 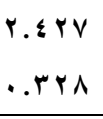 & $7.09 \leq$ & $\cdots$ & r1.7.r & $\cdots$ &. .19 & 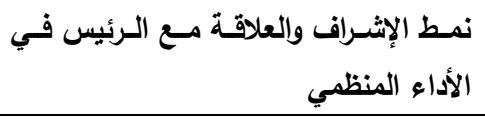 \\
\hline $\begin{array}{l}-.004 \\
. .7 \leq 4\end{array}$ & . . & $\cdots$ & rr..q. & $\cdots$ & 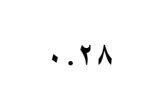 & العلاقة مع الزملاء في الأداء المنظمي \\
\hline $\begin{array}{l}1.7 \mu \mathrm{r} \\
. . \mathrm{r} \leqslant \mathrm{r}\end{array}$ & $0 . .4 \mathrm{~V}$ & $\cdots$ & $10 . r \wedge 1$ & $\cdots$ & $.18 \mathrm{~V}$ & محتـوى العهـل وتتــوع المهـام فـي الأداء \\
\hline $\begin{array}{l}1.4 V 9 \\
0.010\end{array}$ & T.Y^ & $\cdots$ & 70.004 & $\cdots$ & 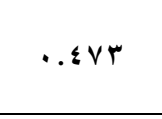 & فرص الأداء المنظمي والتزرقيـة المتاحة للفرد في \\
\hline $\begin{array}{l}.9111 \\
.0990\end{array}$ & r.หq৭ & $\cdots$ & $\{1.191$ & $\cdots$ &.$r \Delta \wedge$ & الرضا الوظيفي في الأداء المنظمي \\
\hline
\end{tabular}

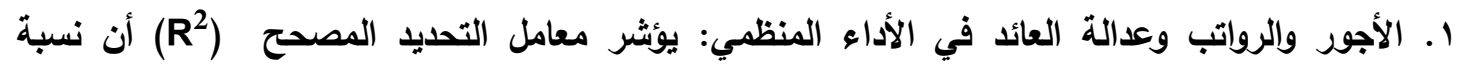
الاختلاف المفسر في الأداء المنظمي بسبب تأثير الأجور والرواتب وعدالة العائد لا تقل عن (r آس. •)، فضلاً

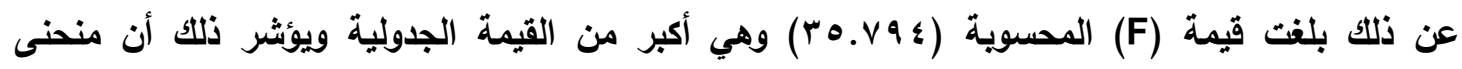

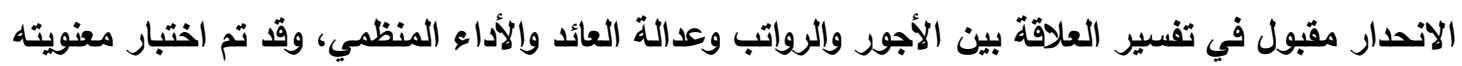

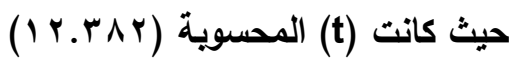

$$
Y=1.979+0.320 \times 1
$$

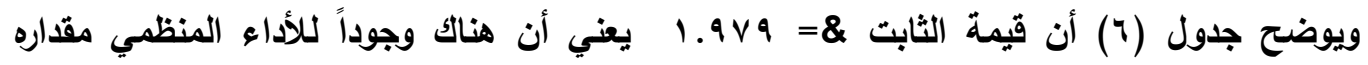

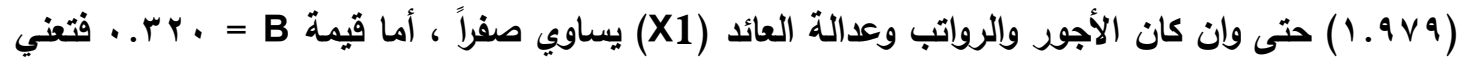

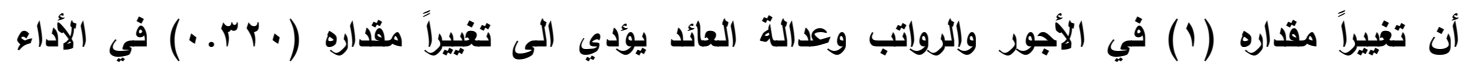

وتعكس هذه النتائج أن الأجور والرواتب وعدالة توزيعها وشعور العاملين في المنظمة بأن ما ينجزوه في العمل يوازي الجها المبذول، لا يمكن للمنظمة إغفاله اذا أرادت أن تحقى أداء مرضي، حيث أنه يساعدا على إيجاد الثعور النفسي بالقناعة والارتياح واثثباعها حاجات ورغبات العاملين.

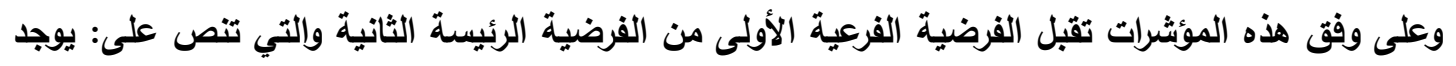
تأثير ذو دلالة معنوية للأجور والرواتب وعدالة العائد في الأداء المنظمي.

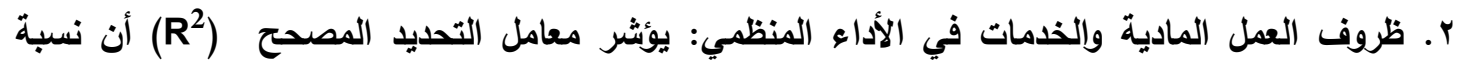

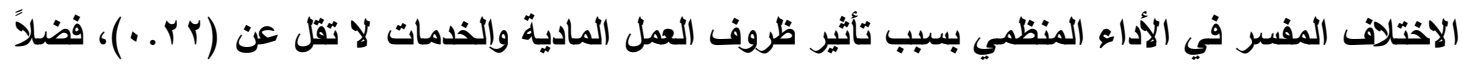

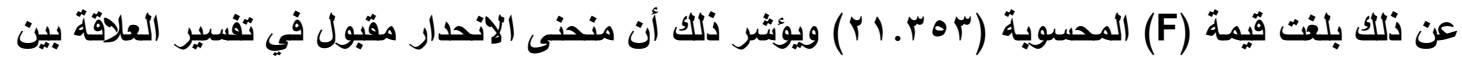




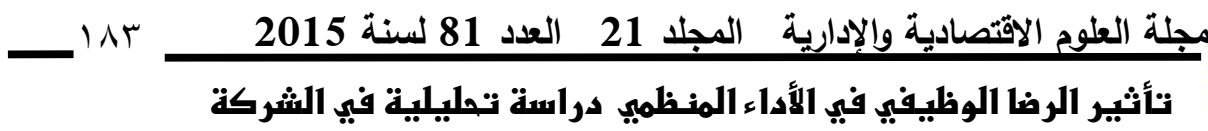

\section{العامة لصناعة البطاريات}

ظروف العمل المادية والخدمات والأداء المنظمي، وقث تم اختبار معنويته حيث كاتت (t) المحسوية $(1 \mathrm{I}$.IVT)

$Y=2.168+0.328 \times 2$

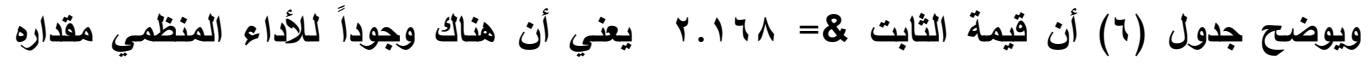

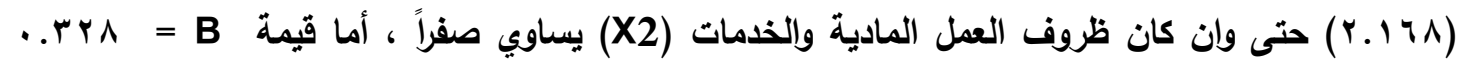

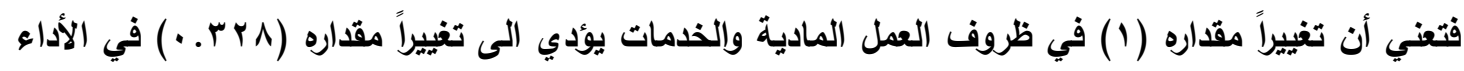

تؤكد هذه النتائج حتمية أهتمام الأدارة العليا بمحيط العمل وتوفير شروط الأمن والسلامة في العمل وتقديم الذدمات الصحية حيث لابد منه في تحقيق الرضا الوظيفي الذي يؤثر بدوره على أداء المنظمة ككل.

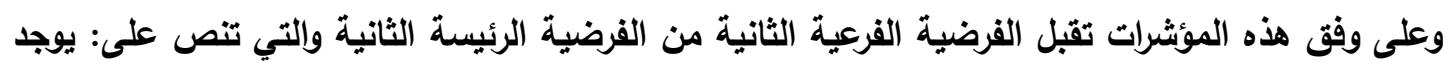
تأثثر ذو دلالة معنوية لظروف العمل المادية والخدمات في الأداء المنظمي.

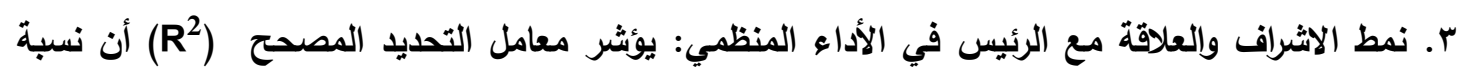

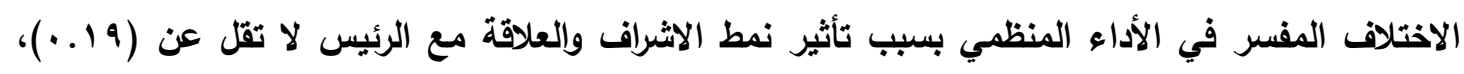

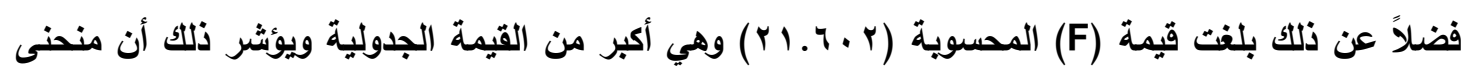

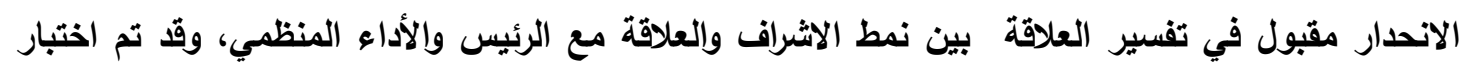

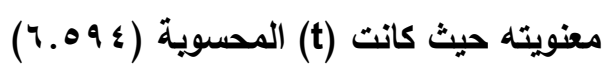

$\mathrm{Y}=2.427+0.328 \times 3$

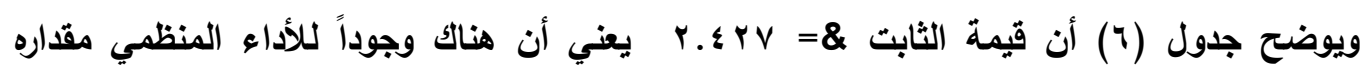

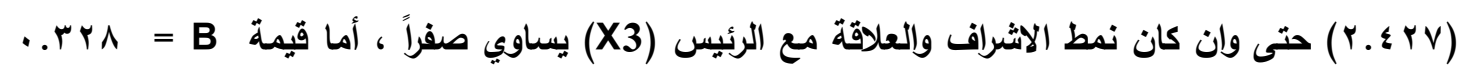

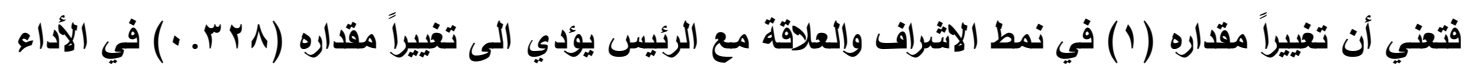

تعكس هذه النتائج وجود تأثير لنمط الاشراف والعلاقة مع الرئيس في الأداء المنظمي ويمكن تفسير

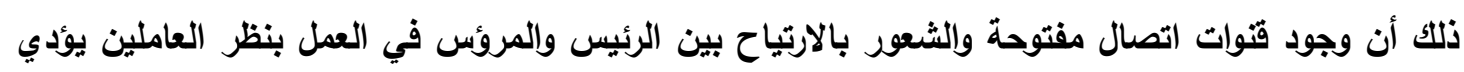

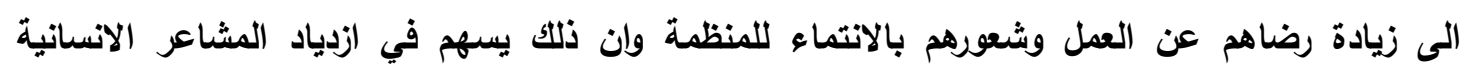
الايجابية الذي يؤدي الى الابداع والعمل الخلاق والتجديد مما يدفعهم الى الأداء الأفضل.

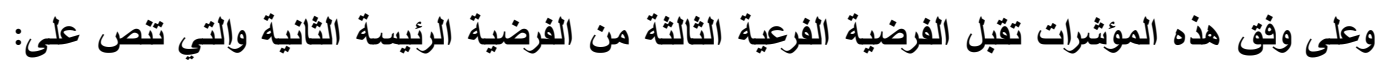
يوجد تأثير ذو دلالة معنوية لنمط الاشراف والعلاقة مع الرئيس في الأداء المنظمي.

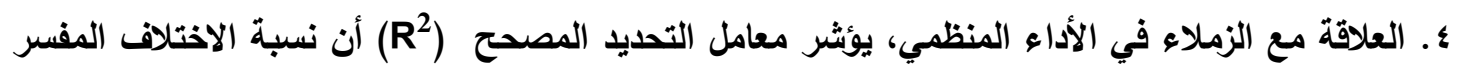

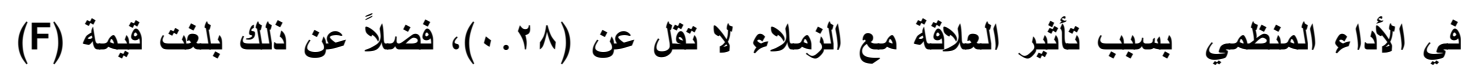

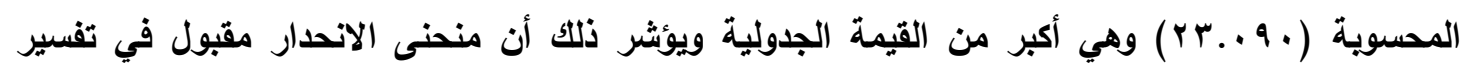

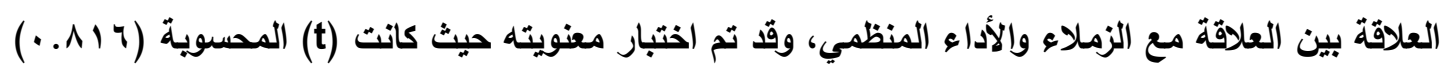




\section{العامة لصنا عة البطاريات}

\section{$Y=0.456+0.646 \quad X 4$}

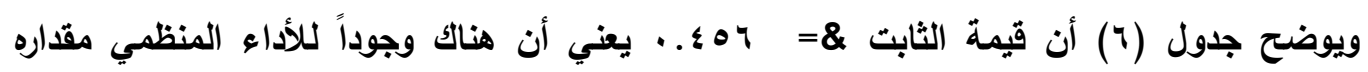

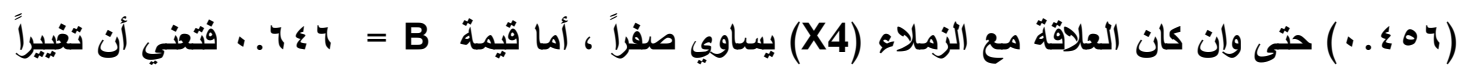

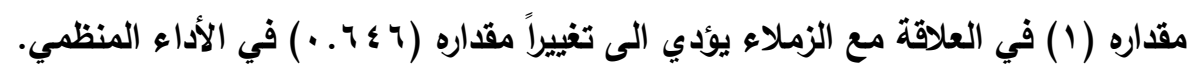
تثير النتائج أعلاه أن مستوى شعور العاملين في المنظمة بارتباطهم بعلاقات ايجابية وتثاركهم في

تبادل الخبرات يشعرهم بالرضا و بدوره يؤثثر ايجابيا في كفاءة وفاعلية أداء المنظمة.

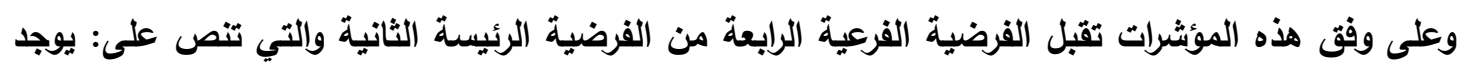
تأثير ذو دلالة معنوية للعلاقة مع الزملاء في الأداء المنظمي.

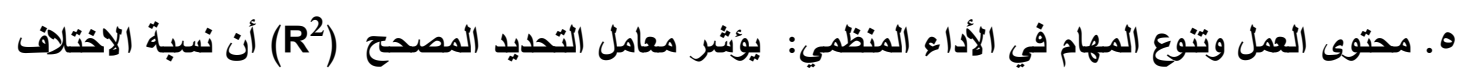

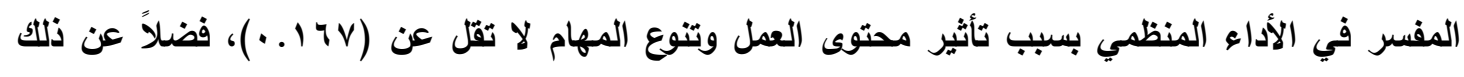

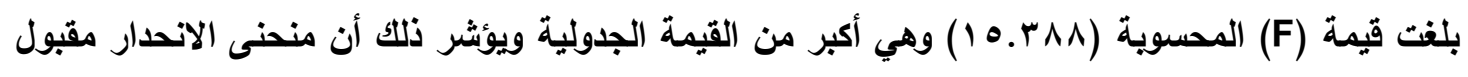

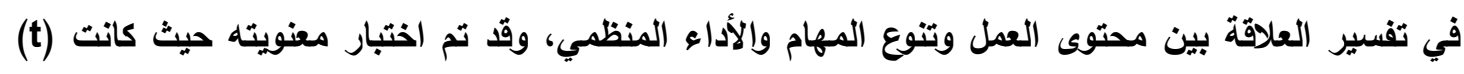

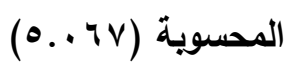

$Y=1.638+0.343 \times 5$

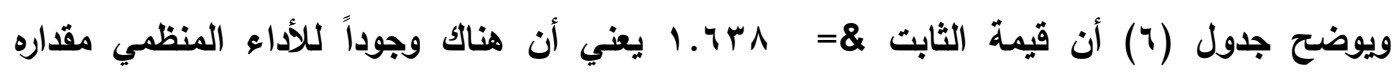

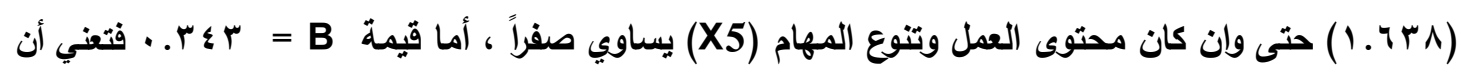

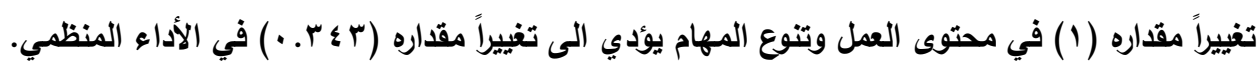

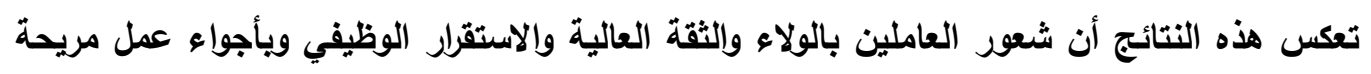

يؤدي الى الاحساس بالرضا وبالتالي يسهم في تحسين كفاءة وفاعلية أداء المنظمة.

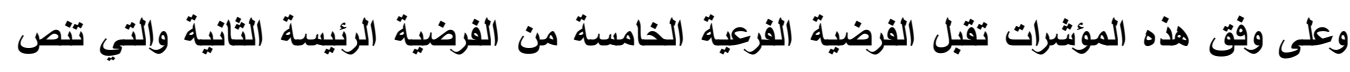

على: يوجد تأثير ذو دلالة معنوية لمحتوى العمل وتنوع المهام في الأداء المنظمي.

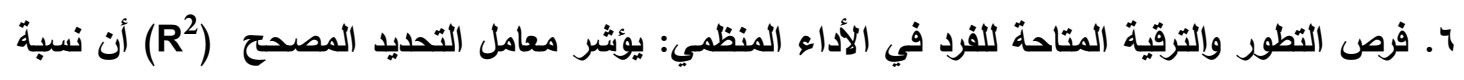

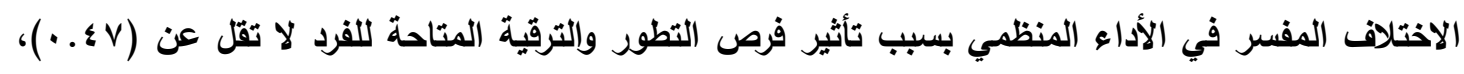

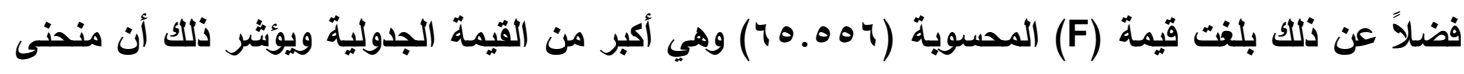

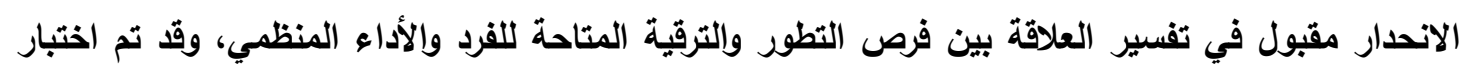

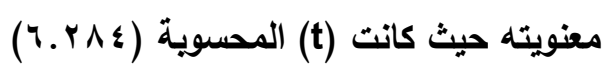

$Y=1.279+0.515 \times 6$

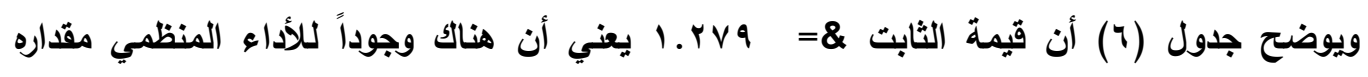

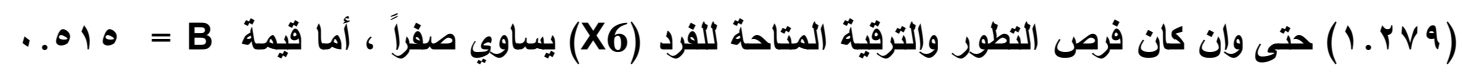

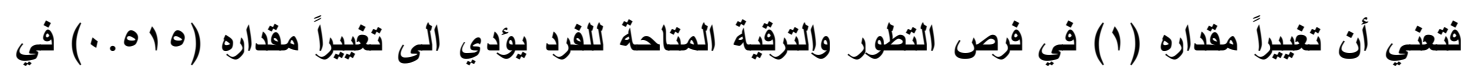
الأداء المنظمي. 


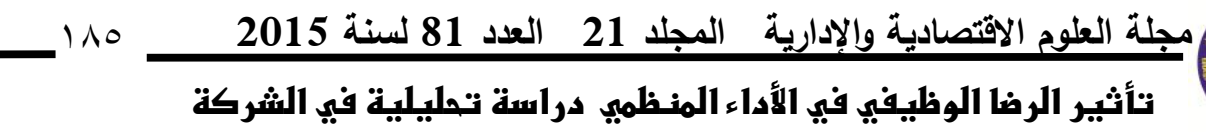

\section{العامة لصناعة البطاريات}

توضح هذه النتائج أن لزيادة كفاءة وفاعلية المنظمة لا بد من توفير فرص لتطوير مهارات العاملين

وزيادة الخبرات المطلوية من خلال البرامج والدورات التدريبية الخارجية والداخلية ومنحهم فرصة للترقية فئية بحسب الاستحقاق.

وعلى وفق هذه المؤشرات تقبل الفرضية الفرعية السادسة من الفرضية الرئيسة الثانية والتي تنص

على: يوجد تأثير ذو دلالة معنوية لقرص التطور والترقية المتاحة للفرد في الأداء المنظمي.

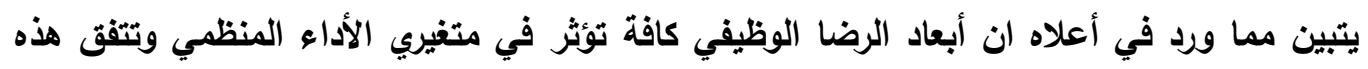

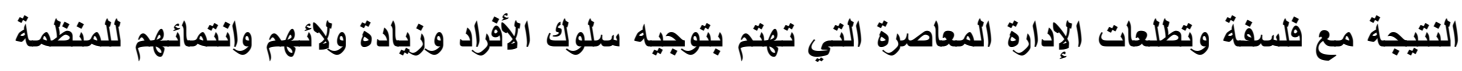
وتحقيق الرغبة لايهم في الانجاز حيث أن استخدام العنصر البشري الأي يتمتع بالرضا الوظيفي يمثل قدرة

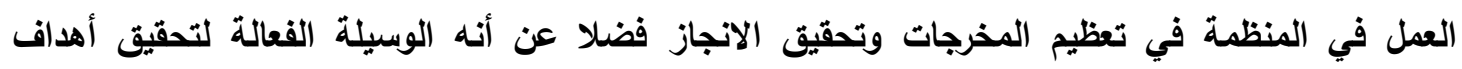

\section{رابعا: الاستنتاجات والتوصيات}

الاستنتتاجات:

1 ـ أكلت عينة الدراسة أن الرضا الوظيفي في الثركة قيد الدراسة بلرجة متوسط حيث بلغ الوسط الحسابي

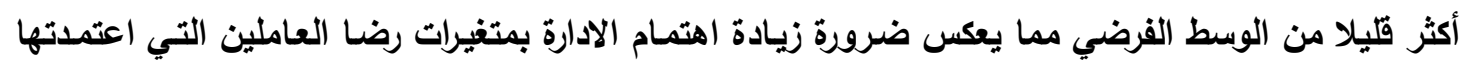
الاسراسة الحالية. r. أثارت الأوساط الحسابية ضعف رضا الأفراد عينة البحث عن الأجور والرواتب وعدالة العائد وكذلك عن

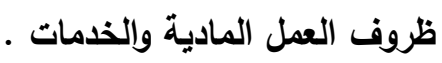
r. احتل متغير العلاقة مع الزملاء أعلى وسطا حسابيا وكان فوق المتوسط في الشركة قيد الدارة و ويعكس

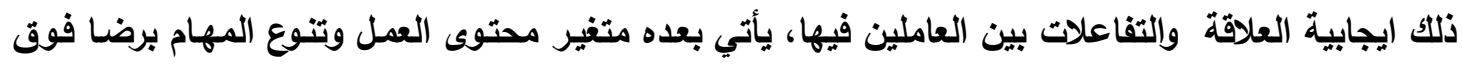

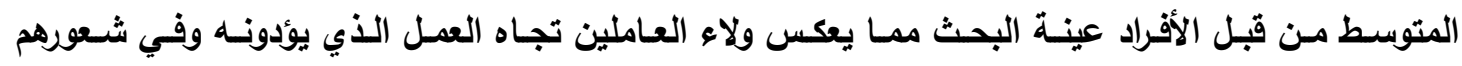

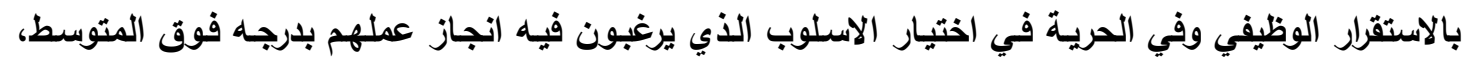
واحتل متفير نمط الاثراف والعلاقة مع الرئيس وسطا حسابيا فوق المتوسط ويفسر ذلك طبيعة العلاقة الطيبة بين العاملين ورئيسهم في العمل، وكان لمتغير فرص التطور والترقية المتاحة للفرد وسطا حسابيا متوسط

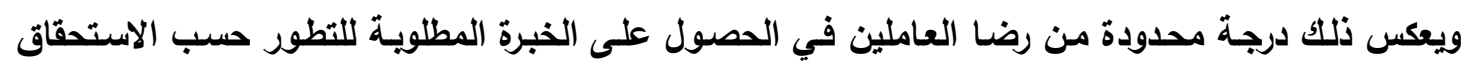

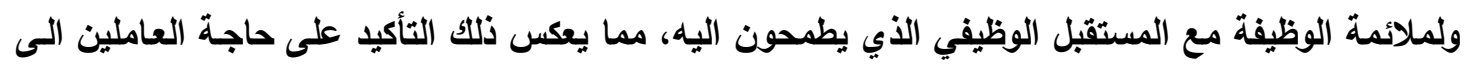
اهتمام أكثر في المتغيرات المذكورة. ع. اثشار الوسط الحسابي الى ضعف الأداء في الثركة قيد الدراسـة، وكذلك بالنسبة الى متغير الفاعلية،

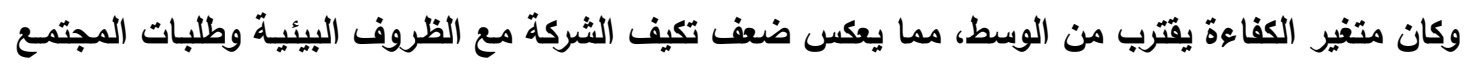

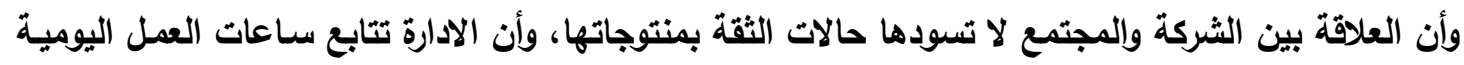




\section{العامة لصناعة البطاريات}

هـ تبين من نتائج البحث أن متغير فرص التطور والترقية المتاحة للفرد كان أكثر متغيرات الرضا الوظيفي

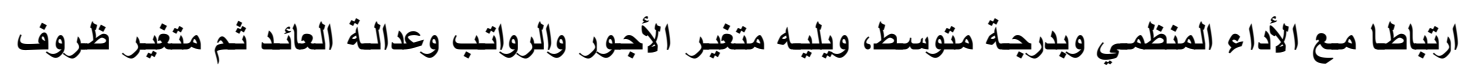

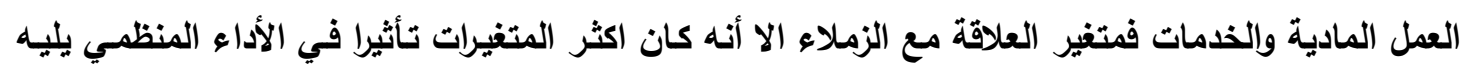
متغير فزص الترقية وإلتطور المتاحة للفرد.

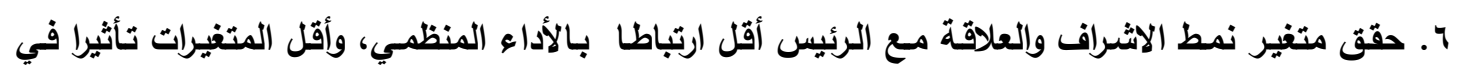
الأداء المنظمي ويفسر ذلك أن العاملين في الثركة بحاجة أكثر الى قتوات اتصـال مفتوحة بينهم ورؤسئواؤهم في العمل والى مشاركة أكثر في القرارات التي تخص مشكي فئلات العمل.

\section{ثانيا: التوصيات}

ا. ـ ضرورة أن تعمل الإدارة العليا في الثركة قيد البحث على زيادة الاهتمام المعرفي للإدارات التابعة إليها

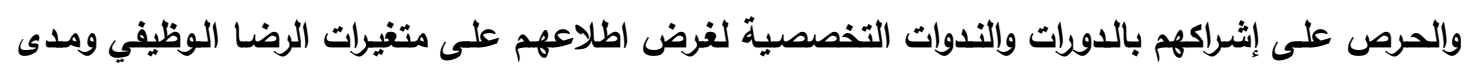

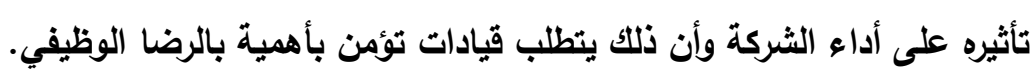

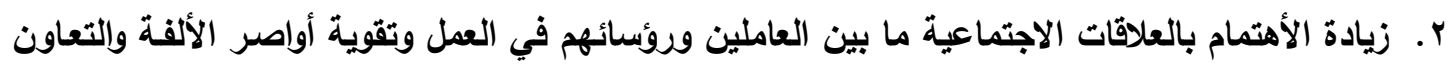

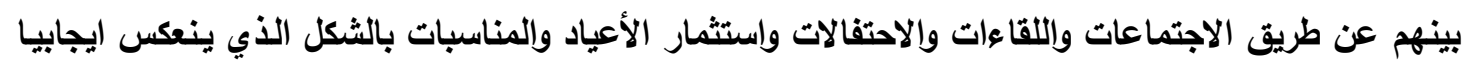
على أداء الثركة. r. ضرورة أن تحرص ادارة الثركة المبحوثة على منح الحوافر والترقية على وفق معايير وضوابط موضوعية تعمل على رفع مستوى كفاءة وفاعلية أداء الثركة وتعزيز ذلك من خلال تحسين ظروف العهد العمل المادية وزيادة

الغدمات المقدمة للعاملين.

ع. . ضرورة اطلاع المرؤوسين على التحديات التي تعاني منها الصناعة المحلية ويالخصوص الشركة قيد

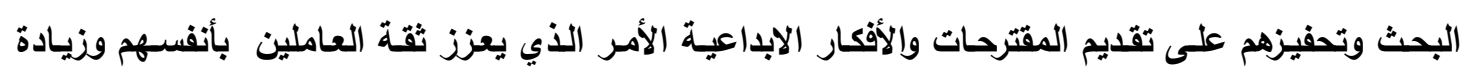

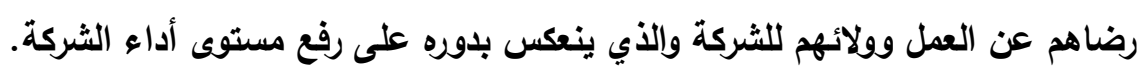

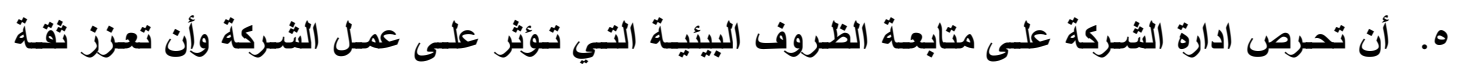

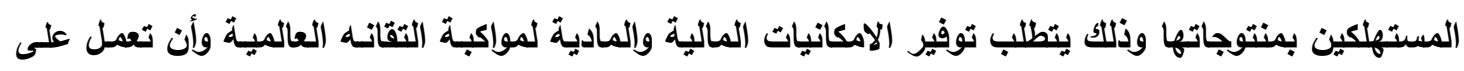

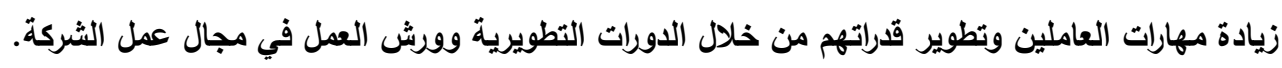

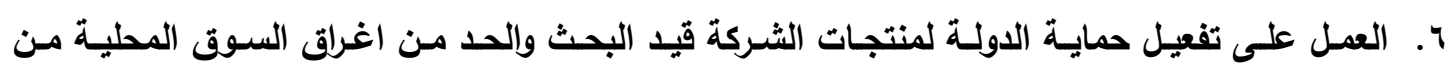
المنتجات الاجنبية المنافسة. 


\section{العامة لصناعة البطاريات}

المصادر العربية:

1. تومسون، آرثر آيه و ستريكلاند، آيه جي، (؟ . . ץ)، "الادارة الاستراتيجية: المفاهيم والحالات العملية"

طا، مكتبة لبنان ناشرون.

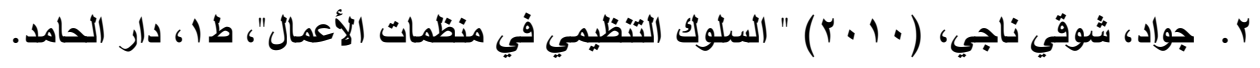

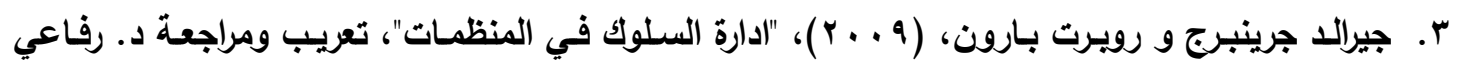

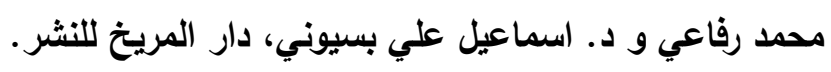

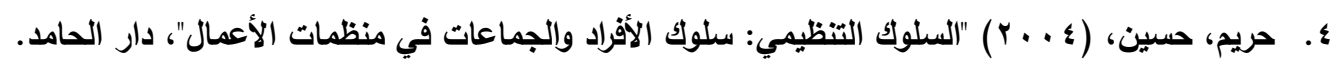

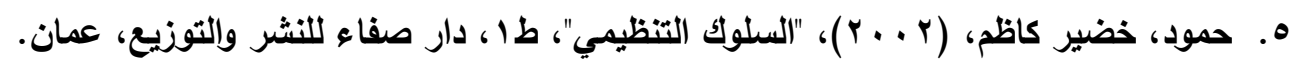

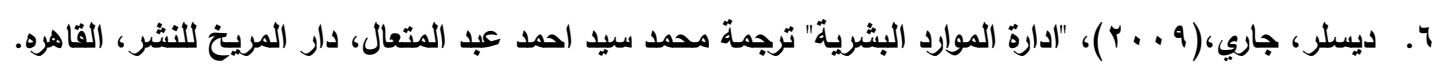

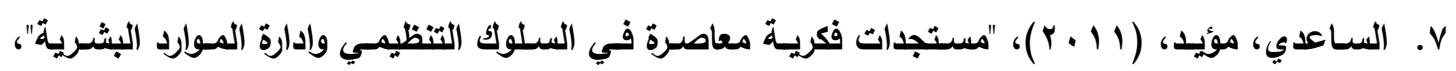

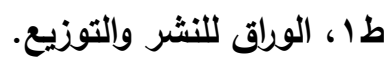

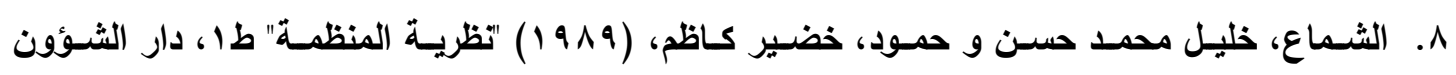
الثقافية، بغداد.

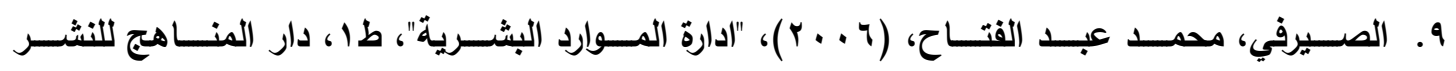
والتوزيع، عمان.

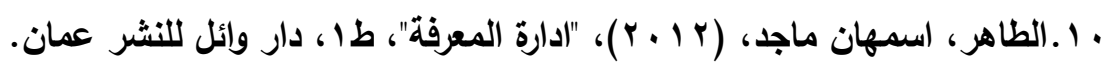

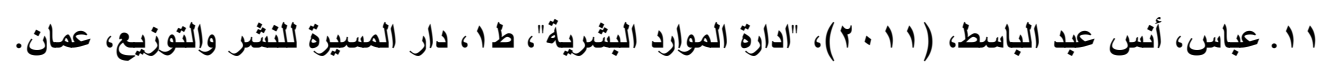

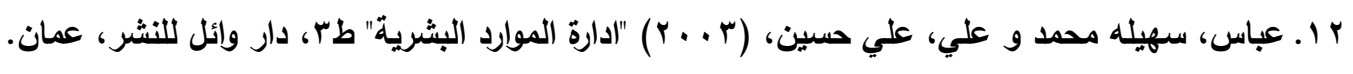

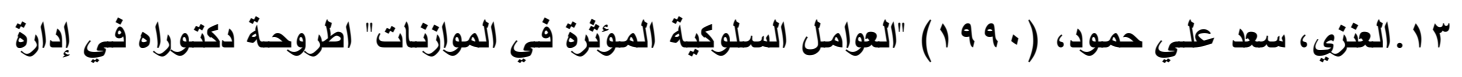

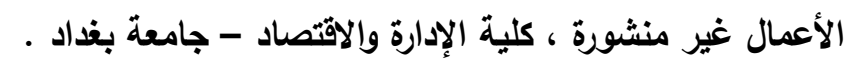

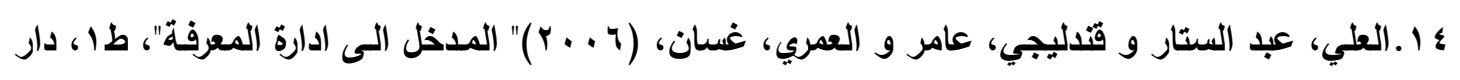
المسيرة للنشر والتوزيع، عمان.

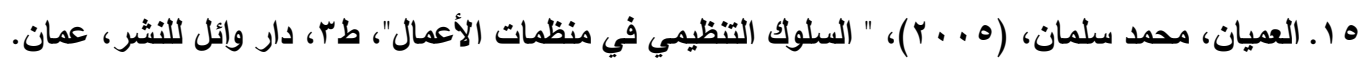

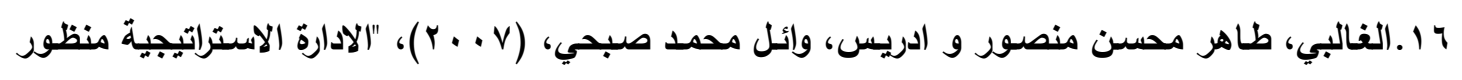

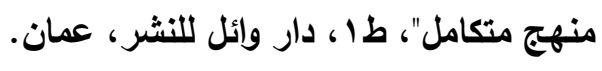

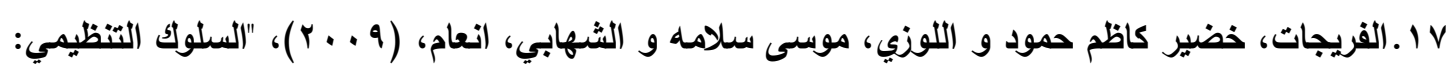

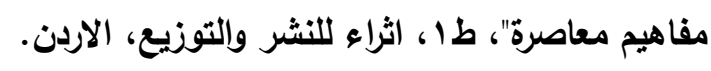

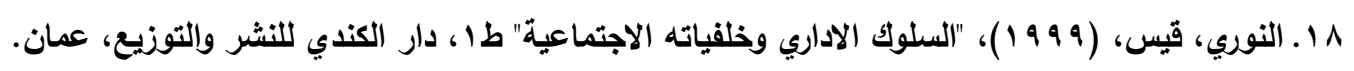

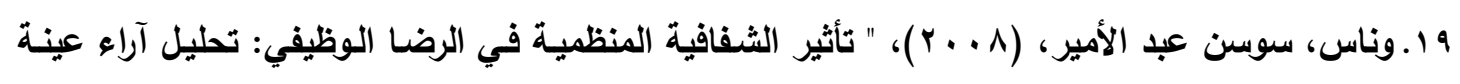

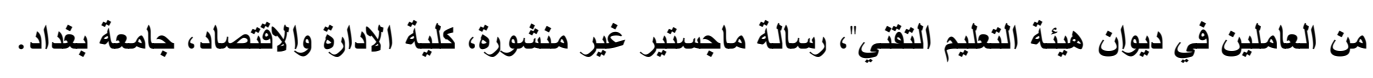


1.Daft, Richara.L.(1992), "Organization theory and Design", $4^{\text {th }}$ ed., west publishing co., Minnesota.

2.Diala, Ify \& Nemani, Rao, (2011), Job satisfaction: Key factors influencing information technology (IT) professionals in Washington Dc, Dr.Rao Nemani, eat al, Int. J.co.Tech. Appl., Vol (2), N(4), pp. 827-838.

3.Gibson, J., Ivancevich,J.M., Donelly,J.H.,\& Konopask,R.,(2003)," Organization: Behavior structure process", $11^{\text {th }}$; Mc Graw Hill Company, Inc., New York.

4.Grimm,Dennis, (2001), "What's Keeping Global corporations Awakeat night?", Management April, Vol(75), No(2).

5.Miller, K., \& Bromiely Philip, (1990) "Strategic Risk \& corporate performance: An analysis of alternative risk measurement" Academy of management Journal, Vol(30), No(4).

6. Morales, Victor. J., \& Montes, Francisco. J., (2006), “Antecedents \& Consequences of Organizational Innovation \& Organizational Learning in Entrepreneur Ship", Industrial Management \& Data Systems, vol (106), N (1), pp. 21-42.

7.Richard L.Hughes, Robert c. Ginnett, Gordon J. Curphy," Leadership: En hanchng the lesson of Experience", (2009), Mc Graw-will companies, New York.

8. Robbins, James, \& Wiersema, Mag F.,(1995), "AResource- Based Approach to the mult Business Firm: Empirical analsis of portfolio international ships and corporate financial performance" Strategic management Journal, Vol(16), No (4).

9.Schermehorn, Jr., John R., Hunt, James G., \& Osborn, Richard N, (2000), "Organizational Behavior" $7^{\text {th }}$ rd., John Wiley \& Sons, Inc., Newyork,

10. Wheelen, Tomas L., \& Hunger, J. David, (2004), "Strategic management and Business policy", 9 ${ }^{\text {th }}$, Pearson, Prentice Hall, New Jersey.

\section{The impact of job satisfaction in Organizational Performance}




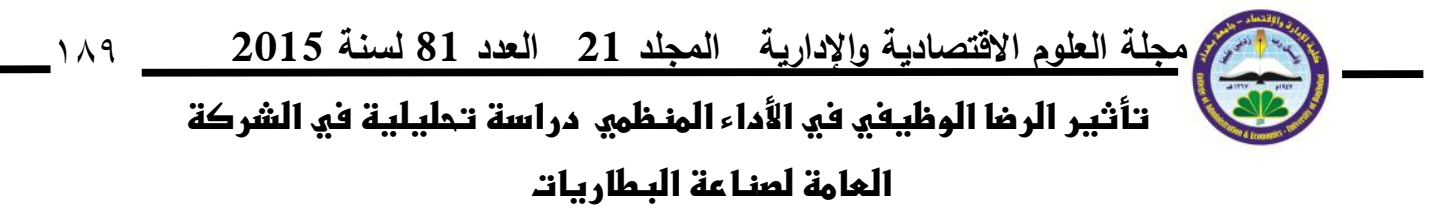

\title{
An analytical study at the General Company for the manufacture of batteries
}

\begin{abstract}
:
This study carry's out the correlation and the effect of two main variables, these variables are Job Satisfaction included six sub: wages - salaries and justice and yield, working conditions and services, pattern of supervision and the relationship with the manger, Relationship with colleagues, the content of the work and the variety of tasks, development and promotion opportunities available to an individual, and Organizational Performance included two sub variables: Efficiency, Effectiveness. This research was conducted using a questioner as a main tool, This questioner was distributed randomly to a research community composed of seventy three working staff at the State Company for Batteries Industries, Resolution allocated two types of information included the first introductory general information about the study sample and the second related variables, the study included forty-six questions.

The study used a number of means for the purpose of statistical analysis of the data based on the statistical program SPSS.20.

The most prominent finding at this study was the positive correlation between Job Satisfaction and Organizational Performance. Job Satisfaction affects Organizational Performance.

In the other hand there was another vital finding at this study which is Job Satisfaction for the working staff was moderate.

Moreover, this study recommends the necessary of the decision makers or high level staff would increase their knowledge to their following staff and make sure they are involved in specialized truing and symposiums, for them to follow up with the latest in Job Satisfaction and its impact on Organizational Performance.

To conduct these results it requires that the leadership believes in the important effect of Job Satisfaction.
\end{abstract}

Key word: Job Satisfaction, Organizational Performance, Efficiency, Effectiveness. 